\title{
Novel Critical Role of Toll-Like Receptor 4 \\ in Lung Ischemia-Reperfusion Injury and Edema
}

Giorgio Zanotti ${ }^{1}$, Monica Casiraghi ${ }^{2}$, John B. Abano ${ }^{3}$, Jason R. Tatreau ${ }^{4}$, Mayura Sevala ${ }^{3}$, Hilary Berlin ${ }^{5}$, Susan Smyth ${ }^{5}$, William K. Funkhouser ${ }^{6}$, Keith Burridge ${ }^{7}$ Scott H. Randell ${ }^{4}$, Thomas M. Egan ${ }^{3}$

1. Division of Cardiac Surgery, San Matteo Hospital, University of Pavia, Pavia, Italy

2. Department of Thoracic Surgery, Vita-Salute San Raffaele University, Milan, Italy

3. Division of Cardiothoracic Surgery, University of North Carolina at Chapel Hill

4. Division of Pulmonary and Critical Care Medicine, Cystic Fibrosis Pulmonary Treatment \& Research Center, University of North Carolina at Chapel Hill

5. Carolina Cardiovascular Biology Center, University of North Carolina at Chapel Hill

6. Department of Pathology and Laboratory Medicine, University of North Carolina at Chapel Hill

7. Department of Cell and Developmental Biology, University of North Carolina at Chapel Hill

Running head: Toll-Like Receptor 4 in Lung IRI

\section{Corresponding author:}

Thomas M. Egan, M.D., MSc.

Division of Cardiothoracic Surgery, University of North Carolina at Chapel Hill 3040 Burnett-Womack Bldg., CB \#7065

Chapel Hill, NC 27599-7065

E-mail: 1txtme@med.unc.edu

Phone: 919-966-3381

Fax: 919-966-3475 


\begin{abstract}
Toll-like receptors (TLRs) of the innate immune system contribute to non-infectious inflammatory processes. We employed a murine model of hilar clamping (one hour) with reperfusion times between 15 minutes and 3 hours in TLR4-sufficient (C3H/OuJ) and TLR4deficient $(\mathrm{C} 3 \mathrm{H} / \mathrm{HeJ})$ anesthetized mice with additional studies in chimeric, MyD88-, and TLR4deficient mice to determine the role of TLR4 in lung ischemia-reperfusion injury. Human pulmonary microvascular endothelial monolayers were subjected to simulated warm ischemia and reperfusion with and without CRX-526, a competitive TLR4 inhibitor. Functional TLR4 solely on pulmonary parenchymal cells, not bone marrow-derived cells, mediates early lung edema following ischemia-reperfusion independent of MyD88. Activation of MAP kinases and NF- $\mathrm{KB}$ was significantly blunted and/or delayed in lungs of TLR4-deficient mice as a consequence of ischemia-reperfusion injury, but edema development appeared to be independent of activation of these signaling pathways. Pre-treatment with a competitive TLR4 inhibitor prevented edema in vivo and reduced actin cytoskeletal rearrangement and gap formation in pulmonary microvascular endothelial monolayers subjected to simulated warm ischemia and reperfusion. In addition to its well-accepted role to alter gene transcription, functioning TLR4 on pulmonary parenchymal cells plays a key role in very early and profound pulmonary edema in murine lung ischemia-reperfusion injury. This may be due to a novel mechanism - regulation of endothelial cell cytoskeleton affecting microvascular endothelial cell permeability.
\end{abstract}

Key Words: ischemia-reperfusion injury; microvascular permeability; toll-like receptor 4; endothelial cell; pulmonary edema 


\section{Introduction}

Acute lung injury is a feature of sepsis, systemic inflammatory response, and adult respiratory distress syndrome. Non-cardiogenic pulmonary edema and impaired gas exchange are consequences of acute lung injury, irrespective of etiology. The mechanisms causing pulmonary edema due to acute lung injury are not well understood. Ischemia-reperfusion injury (IRI), a form of acute lung injury occurring immediately following lung transplantation, is a frequent complication causing morbidity and mortality.(26) A greater understanding of lung IRI is likely relevant to many types of acute lung injury, and thus may benefit not only lung transplant recipients but substantial numbers of other patients with lung injury. Such knowledge would also facilitate retrieval of lungs from non-heart-beating cadaver donors for transplant, and/or may assist in the salvage of lungs not considered suitable for transplant, thereby reducing the critical shortage of transplantable lungs. $(8,11)$

Reperfusion following an interval of ischemia results in an inflammatory response involving components of the innate immune system, including the complement and coagulation cascades. Both parenchymal and myeloid cells elaborate free radicals, nitric oxide, and pro- and anti-inflammatory cytokines. $(4,5)$ Recently, there has been increasing awareness of the important contribution of the innate immune system, particularly the toll-like receptors, to a variety of non-infectious inflammatory processes.(31)

Toll-like receptor-4 (TLR4) is the mammalian LPS receptor.(3) Upon stimulation, TLR4 activates the innate immune system by phosphorylation of mitogen activated protein kinases (MAPKs) and activation of NF-кB.(34) In an earlier study, increased expression of ICAM-1 following lung transplantation was due to reperfusion, not the antecedent ischemia per se.(9) Interestingly, ICAM-1 expression was increased and lung histology was similar 6 hours after 
LPS administration and 6 hours following lung transplantation. Thus, we hypothesized that TLR4 contributed to acute lung injury due to IRI. We tested this hypothesis in a murine model of in situ left-lung IRI, comparing TLR4-deficient mice (C3H/HeJ) to TLR4-sufficient mice $(\mathrm{C} 3 \mathrm{H} / \mathrm{HeOuJ})$. Functioning TLR4 not only contributes to the inflammatory response via MAPK and NF- $\mathrm{BB}$ signaling, but TLR4 also mediates rapid lung edema upon reperfusion of ischemic lung. We confirmed this in TLR4-/- mice. In vitro, alteration of pulmonary microvascular endothelial cytoskeleton occurs during simulated ischemia-reperfusion; this was substantially reduced in our model by CRX-526, a competitive inhibitor of TLR4,(14) implying a possible mechanism for TLR4-mediated pulmonary edema due to IRI. Pre-treatment of mice with CRX526 also reduced edema formation.

Portions of this work have been presented at national meetings and appear in print as published abstracts. $(1,56,57)$

\section{Materials and Methods}

Male C3H/HeJ, C3H/OuJ, TLR4-/- and C57BL/6J mice were purchased from Jackson Laboratories (Bar Harbor, ME) and MyD88-/- mice were provided by Dr. Akira, Kyoto, Japan. Mice were maintained in a pathogen-free facility until they weighed 25-30 grams and were 8-10 weeks old. Reagents were from Sigma (St. Louis, MO) unless specified. Animal experimental protocols were approved by the University of North Carolina Institutional Animal Care and Use Committee.

Surgical Model of Murine Lung IRI

Mice were anesthetized with ketamine $(0.1 \mathrm{mg} / \mathrm{gm}$ body weight $)$ and xylazine $(0.01$ $\mathrm{mg} / \mathrm{gm}$ ) intraperitoneally, followed by one-third of the initial dose hourly. Tracheotomy allowed 
mechanical ventilation with a tidal volume of $0.4 \mathrm{ml}$, respiratory rate 120/min, I/E 0.4 , PEEP 3 cm $\mathrm{H}_{2} \mathrm{O}, \mathrm{FiO}_{2} 1.0$ (CIV-101, Columbus Instruments, Columbus, $\left.\mathrm{OH}\right)$. The right jugular vein was cannulated for infusion of albumin $2.5 \%$ in $0.9 \%$ saline, $450 \mu \mathrm{l} /$ hour by syringe pump (Medfusion 2010i, Medex, Carlsbad, CA) to maintain hydration. Rectal temperature was monitored and maintained with a heating pad. The left pulmonary hilum was occluded for 1 hour with a microvascular clamp through a left thoracotomy. Reperfusion began with removal of the clamp. Animals were sacrificed at intervals ranging from 15 minutes to 3 hours by cardiectomy, and both lungs were excised. The apical portion of each lung was excised and immediately weighed, then desiccated in a $60^{\circ} \mathrm{C}$ oven for 48 hours and re-weighed to determine wet:dry weight ratio (W/D) Remaining lung tissue was flash frozen in liquid nitrogen, and stored at $-80^{\circ} \mathrm{C}$. Lungs excised immediately after sacrifice served as controls.

Extravascular albumin extravasation with Evans blue dye (EBD)

Extravascular albumin extravasation after 1 hour IRI was assessed by the Evans blue dye (EBD) technique(39). After occlusion of the left hilum, $30 \mathrm{mg} / \mathrm{kg}$ of EBD dissolved in $250 \mu 1$ of $0.9 \%$ saline solution were injected into the right jugular vein. After 1 hour of reperfusion, the chest was opened through a median sternotomy, the mice were euthanized by right ventriculotomy, the pulmonary trunk cannulated with an 18G Angiocath, and the left atrial appendage amputated. Both lungs were flushed with normal saline to remove intravascular EBD, excised and weighed. The lung tissue was suspended in formamide (100 mg lung tissue/1 mL formamide, Roche Diagnostics, Indianapolis, IN) and incubated for 24 hours at $50^{\circ} \mathrm{C}$. Specimens were then centrifuged $(13,000 \mathrm{~g}$ x 30 minutes $)$, and $50 \mu \mathrm{L}$ of supernatant were placed in 96 -well plates for colorimetric assessment in a $\mu$ Quant spectrophotometer (Bio-Tek instruments, Inc., Highland Park Vinooski, VT) at $620 \mathrm{~nm}$. Relative optical density values were normalized by the 
weight of the samples.

Inflation fixation for histology

After 60 or 180 minutes of IRI ( $n=4 /$ strain/group), lung blocks were inflation-fixed through the trachea with $4 \%$ buffered paraformaldehyde at a constant pressure of $25 \mathrm{~cm} \mathrm{H}_{2} \mathrm{O}$ for 24 hours at room temperature, then embedded in paraffin. Five micron sections were stained with hematoxylin and eosin. Lungs from animals sacrificed immediately after tracheotomy ( $n=4 /$ strain $)$ served as controls.

\section{Immunostaining for $N F-\kappa B$ translocation}

Immunohistochemical staining of inflation fixed lung tissue was performed using a rabbit polyclonal p65 antibody (ab 31481, Abcam, UK) at a 1:100 dilution. Samples were sectioned at 5um, dried overnight and baked at $60^{\circ} \mathrm{C}$ for one hour. Sections were deparaffinized and epitope retrieval was done with $6.0 \mathrm{pH}$ Citra Antigen Retrieval Buffer (Dakocytomation, CA, USA) for $30 \mathrm{~min}$ at $100^{\circ} \mathrm{C}$. Background was blocked using a Peroxidase block, a serum-free Protein Block, and an Avidin/Biotin block (Dakocytomation). Sections were incubated with the primary antibody p65 overnight at $4{ }^{\circ} \mathrm{C}$. Detection was completed with the LSAB+ secondary antibody along with a DAB chromagen for visualization (Dakocytomation). No counterstain was applied. Slides were scored for p65 nuclear staining by a pathologist blinded to specimen group and graded as $1+$ (mild, some nuclear staining evident), 2+ (moderate, some intense staining, but not consistent) or $3+$ (dark consistent staining of virtually all nuclei).

\section{Protein extraction and Immunoblotting}

Protein concentration measurement and immunoblotting were performed as previously described.(54) Briefly, frozen lung tissue was suspended in $10 \mu 1 / \mathrm{mg}$ ice-cold RIPA lysis buffer (100mM Tris- $\mathrm{HCl} \mathrm{pH} \mathrm{8.0,} 100 \mathrm{mM} \mathrm{NaCl}, 5 \mathrm{mM} \mathrm{NaF}, 2 \mathrm{mM}$ EDTA, 1\% NP-40, $1 \mathrm{mM} \mathrm{Na}_{3} \mathrm{VO}_{4}$, 
$100 \mu \mathrm{M}$ TPCK, $1 \mu \mathrm{M}$ pepstatin A, $2 \mu \mathrm{M}$ leupeptin, $1 \mathrm{mM}$ PMSF, $100 \mu \mathrm{M}$ quercetin), Dounce homogenized, and centrifuged at 13,200 rpm for 10 minutes at $4^{\circ} \mathrm{C}$ to remove insoluble material. Supernatant protein concentrations were determined using the Coomassie Protein Assay Reagent (Pierce Biotechnology, Rockford, IL). After addition of $\beta$-mercaptoethanol (5\%) and tracking dye, samples were denatured, and equivalent amounts of protein were resolved by SDS-PAGE (10\% tris-glycine or 4\%-12\% bis-tris gels, Invitrogen, Carlsbad, CA) and transferred onto Immobilon-P membranes (Millipore Corp., Billerica, MA). Blots were blocked in TBS with $0.1 \%$ Tween-20 and 5\% nonfat dry milk powder for 1 hour, incubated with primary then secondary antibodies, followed by chemiluminescent detection of peroxidase (Millipore). Antibodies against phosphorylated or total JNK, p38, ERK, and I $\mathrm{B} \alpha$ were purchased from Cell Signaling Technology (Beverly, MA). Films were scanned at 600 dpi in 16-bit grayscale on an Epson Precision 4180 flatbed scanner. Densitometry was performed using MetaMorph® software (Universal Imaging Corp, Downingtown, PA).

Bone Marrow Transplant (BMT)

Chimeric mice were generated by BMT.(40) Recipient mice were exposed to 12 Gy lethal irradiation (Gammacell $40{ }^{137} \mathrm{Cs} \gamma$-irradiation source; Nordion, Ottawa, Canada), delivered in 2 doses separated by 4 hours ( $700 \mathrm{cGy}$, then $500 \mathrm{cGy}$ ). Bone marrow was obtained from donor mice by flushing their femurs and tibias with medium (Roswell Park Memorial Institute (RPMI) buffer $+10 \%$ fetal bovine serum (FBS) +100 units Heparin + 1M HEPES). Harvested marrow cells were passed through a $0.2 \mu \mathrm{m}$ filter, enumerated and resuspended to a concentration of $10^{6}$ cells in $200 \mu \mathrm{l}$ of sterile PBS $+10 \%$ FBS. Marrow cells were then injected retro-orbitally into recipients immediately after they received the second dose of $\gamma$-radiation. Recipient mice were maintained in sterile microisolator cages for 12 weeks to allow full humoral reconstitution. 
Four sets of chimeras were created to produce mice with functional TLR4 $(+)$ on parenchymal cells $(\mathrm{P})$, or myeloid cells $(\mathrm{M})$ : HeJ mice had marrow reconstituted from OuJ donors (P-M+); OuJ mice had marrow reconstituted from HeJ mice (P+M-); “control” chimeras were generated by reconstituting marrow from the same strains $(\mathrm{P}-\mathrm{M}-)$ and $(\mathrm{P}+\mathrm{M}+)$.

\section{Cell Culture Model of Warm Lung IRI}

Because mice were ventilated with $100 \% \mathrm{O}_{2}$ prior to hilar clamping, our in vivo model of IRI was likely not associated with lung hypoxia. Thus we developed an in vitro normothermic $\left(37^{\circ} \mathrm{C}\right)$ model of IRI employing nutrient depletion in $100 \%$ oxygen to model ischemia, with reperfusion modeled by supplying fresh medium to culture dishes in sealed Plexiglas containers. Human pulmonary microvascular endothelial cells (HMVECs) (Cambrex Bio Science, Walkersville, MD) maintained in Clonetics ${ }^{\circledR}$ EGM-2 MV BulletKits ${ }^{\circledR}$ medium (Cambrex), at $37^{\circ} \mathrm{C}$ in a humidified incubator in $5 \% \mathrm{CO} 2$ were seeded at 2000 cells $/ \mathrm{cm}^{2}$ on collagen-coated 30 mm diameter glass bottom dish coverslips (Mattek Corp. Ashland, MA) and grown until 100\% confluent. Sealed Plexiglas containers housing culture dishes at $37^{\circ} \mathrm{C}$ were ventilated with $95 \%$ $\mathrm{O}_{2} / 5 \% \mathrm{CO}_{2}$. To model warm ischemia (WI), cell medium was suddenly replaced with $2 \mathrm{ml}$ nutrient-depleted clinical grade Ringer's lactate (RL) containing $100 \mathrm{U} / \mathrm{ml}$ penicillin and 100 $\mu \mathrm{g} / \mathrm{ml}$ streptomycin and the chamber was ventilated with $100 \% \mathrm{O} 2$. Dishes were pre-treated with $1 \mu \mathrm{g} / \mathrm{ml}$ CRX-526 (GlaxoSmithKline, Duluth, MN), a competitive inhibitor of TLR4,(14) or vehicle (2\% Glycerin), one hour before WI. CRX-526 or vehicle was added whenever medium was changed. After 1 hour of simulated WI, RL was replaced with EGM2-MV medium to simulate reperfusion, ventilating the chamber with $5 \% \mathrm{CO}_{2}$ in room air. Dishes were removed in triplicate during WI and reperfusion, and immediately fixed in 4\% paraformaldehyde for phalloidin staining. Cells with inhibitor or vehicle maintained in EGM2-MV medium at $37^{\circ} \mathrm{C}$ in 
humidified 5\% CO2 incubator served as controls. Culture medium was changed at the same time that medium was changed in experimental dishes. Probes inserted through sealed ports continuously recorded temperature, and $\mathrm{pH}$ in a representative dish in the Plexiglas box using voltmeters with data output recorded by PicoRecorded software (Pico, St Neots, UK).

Phalloidin staining and image analysis

HMVECs were fixed in 4\% paraformaldehyde for 10 minutes at room temperature and washed 3 times with PBS. Cells were incubated for 1 hour with a 1/100 dilution of Alexa Fluor ${ }^{\circledR}$ 568 phalloidin (Invitrogen, Carlsbad, CA) in PBS with 1\% BSA and 0.05\% Tween-20.

Coverslips stained for F-actin were immediately examined with a Leica DMIRB Inverted Fluorescence/DIC microscope at 20X and 40X magnification to evaluate changes in cell shape and F-actin cytoskeleton. For each dish, three pictures were taken of contiguous fields near the center of the dish at $40 \mathrm{X}$ with a Kodak digital camera at the same exposure time. A masked observer assessed actin stress fiber pattern of each cell as normal or abnormal. Quantitative analysis of gap area was performed using Metamorph ${ }^{\circledR}$ software. A second masked observer evaluated the pattern of actin stress fibers in photographs grouped at the same time points.

\section{Determination of viability for cell culture experiments}

In separate experiments performed in triplicate, HMVECs grown to confluence on P35 dishes underwent simulated IRI. At the same time points, cells and cell culture media or Ringer's lactate were assessed for lactate dehydrogenase (LDH) activity using the CytoTox96 NonRadioactive Cytotoxicity Assay following the manufacturer's instructions (Promega, Madison, WI). Control samples were also taken at time zero and 24 hours to assess cell viability apart from the experimental model. Culture medium and Ringer's lactate were used as background controls to normalize the absorbance value from the other samples. Cytotoxicity was calculated as media 
LDH activity divided by total LDH activity (cell pellet plus media). Viability was the inverse and expressed as percent viability at each time point.

Bronchoalveolar Lavage (BAL) and Alveolar Macrophage (AM) Cell Culture

AMs from HeJ and OuJ mice were harvested by BAL 120 days after BMT. The trachea was cannulated with a tailored 18 gauge catheter (Becton Dickinson, Sandy, UT). BAL was performed by slow tracheal delivery of 4 aliquots ( $35 \mu 1 \mathrm{x}$ body weight in grams) of pre-warmed, sterile, endotoxin-, calcium- and magnesium-free, PBS with 0.2 mM EGTA. Lavage fluid was withdrawn by gentle suction, pooled for each mouse, and centrifuged at $250 \mathrm{~g}$ for 5 minutes. Cells were resuspended in RPMI 1640 (Gibco BRL, Rockville, MD) containing 10\% heatinactivated FBS (Atlanta Biologicals, Lawrenceville, GA), penicillin G (100 U/ml), and streptomycin $(100 \mu \mathrm{g} / \mathrm{ml})$. Viability was consistently $>95 \%$ by trypan blue exclusion. Cells were plated at 20,000 per well in 96-well plates. After 2 hours of incubation, plates were washed with PBS to remove non-adherent cells. Adherent AMs were cultured in RPMI 1640 at $37^{\circ} \mathrm{C}$ in a humidified incubator with $5 \% \mathrm{CO}_{2}$.

$N F-\kappa B$ Reporter Assay

Recombinant, first-generation E1, E3-deleted adenovirus serotype 5 vectors were prepared by the UNC Gene Therapy Center Vector Core,(38) and HMVECs and AMs were transfected as previously described for epithelial cells.(54) Statistical Analysis

All data are reported as mean \pm SEM. Groups were compared by ANOVA with Tukey's post hoc test or by paired or unpaired t tests using Statistica ${ }^{\circledR}$ (Tulsa, OK).

\section{Results}

TLR4 Is a Key Mediator of Early Pulmonary Edema Due to IRI 
Reperfusion of left lungs rendered ischemic by 1 hour of hilar clamping induced early, pronounced fluid accumulation manifest by elevated W/D in the left lung of TLR4-sufficient (OuJ) mice within 15 minutes of reperfusion that persisted out to 3 hours of reperfusion (Figure 1A). In contrast, TLR4-deficient (HeJ) mice experienced significantly less edema following 15 and 30 minutes reperfusion, and demonstrated earlier recovery; W/D after 1 and 3 hours reperfusion was normal.

There was more perivascular and alveolar wall edema in inflation-fixed OuJ left lungs reperfused for 3 hours compared to HeJ lungs (Figure 1B). However, there was no histologic difference in interstitial edema between strains after 1 hour reperfusion (Figure 1C). All 8 lung specimens after one hour reperfusion and $4 \mathrm{HeJ}$ specimens after 3 hours reperfusion were judged to be normal and not different from 4 Control specimens ( $2 \mathrm{Hej}, 2 \mathrm{OuJ}$ ) by a masked observer. We postulated that the increased interstitial edema in OuJ lungs after 3 hours reperfusion was due to rapid alveolar flooding rendered undetectable by inflation fixation 60 minutes after reperfusion. Consistent with this hypothesis, left lungs from OuJ mice had increased Evans blue dye content (a measure of microvascular permeability to albumin(39)) compared to left lungs from HeJ mice and right lungs from both strains (Figure 1D). Thus, the difference in W/D was due to alveolar flooding occurring early in OuJ mice compared to HeJ mice, with later absorption of the fluid into the alveolar walls and interstitium.

TLR4 signaling downstream of receptor activation involves recruitment of adapter proteins including MyD88 and TRIF.(34) Because TRIF is not present in murine endothelial cells,(16) MyD88 signaling is the key adapter downstream of TLR4 in these cells. When we subjected MyD88-/- mice to 1 hour of IRI, equivalent edema developed in MyD88-/- mice as in OuJ mice and C57BL/6J mice, the background strain for MyD88-/- mice (Figure 1E). Thus 
TLR4-mediated lung edema due to IRI is independent of downstream signaling via the MyD88 adapter. To confirm that early edema was due to TLR4, we repeated experiments in TLR4-/mice, compared to C57BL/6J mice, the background strain. Figure 1F confirms that TLR4-/- mice had significantly less edema compared to C57BL/6J mice after one hour hilar clamping and reperfusion for 15,30 , or 60 minutes. Response to lung injury differs among mouse strains. $(2,6)$ Perhaps this is an explanation for slightly increased W/D in right lungs of C57BL/6J mice with increased reperfusion times, and why there is still some persistent edema in left lungs of TLR4-/mice after $60 \mathrm{~min}$ reperfusion, although the temporal pattern and extent of edema development is very similar to the TLR4-defective HeJ strain.

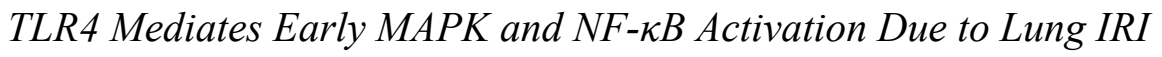

HeJ mice demonstrate delayed (p38, ERK) or reduced $(\mathrm{NF}-\kappa \mathrm{B}, \mathrm{JNK})$ activation compared to early and sustained activation in OuJ mice (Figure 2). Because some degree of MAPK and NF- $\mathrm{BB}$ activation was observed in HeJ mice, alternative pathways independent of functioning TLR4 are implicated. Immunostaining for the p65 component of NF- $\kappa \mathrm{B}$ confirmed the time course of NF- $\kappa \mathrm{B}$ activation depicted by $\mathrm{I} \kappa \mathrm{B} \alpha$ degradation (Figure 3). Surprisingly, NF$\kappa \mathrm{B}$ was activated in the right lung to the same extent at the same reperfusion times despite the lack of edema in the right lung. Thus, NF- $\kappa \mathrm{B}$ activation is not necessarily associated with edema development. p38 activation was apparent in left lungs from HeJ mice 3 hours after reperfusion, with normal W/D. Taken together with the rapidity of development, the acute phase pulmonary edema in this model does not appear to be due to MAPK or NF- $\kappa$ B activation.

\section{TLR4 on Lung Parenchymal Cells is Necessary for Edema Formation Due to Lung IRI}

To determine the importance of functioning TLR4 on lung parenchymal versus bone marrow-derived cells, particularly alveolar macrophages (AMs), we created chimeric mice by 
lethally irradiating mice of each strain and re-constituting bone marrow by BMT. Replacement of AMs in chimeric animals was virtually complete 12 weeks after BMT (Figure 4A). In chimeric animals after 3 hours of IRI, edema is apparent only when functional TLR4 is present on lung parenchymal cells (P), whether or not functioning TLR4 is present on myeloid cells (M) (Figure 4B). The presence of TLR4-sufficent AMs or other myeloid cells does not result in lung edema if parenchymal cells do not possess functional TLR4 (P-M+). Chimeric controls (OuJ into OuJ and $\mathrm{HeJ}$ into HeJ) showed no difference in pulmonary edema formation compared to nonirradiated strains (Figure 4C), demonstrating that lethal irradiation had no impact on development of edema due to IRI. AMs from these "control chimerics" had the same response to LPS as AMs from the native strains (data not shown). Thus, early edema formation due to IRI is attributable to functioning TLR4 on lung parenchymal cells. A Competitive Inhibitor of TLR4 Prevents Pulmonary Edema Due to IRI

CRX-526 administered intravenously over 30 minutes (10 $\mu \mathrm{g}$ in $200 \mu \mathrm{l}$ of saline) to OuJ mice 30 minutes before left hilar clamping prevented edema following 1 hour of IRI (Figure 5A). CRX-526 also prevented NF-kB activation in cultured human pulmonary microvascular endothelial cells (HMVECs) exposed to LPS (Figure 5B). Simulated Warm Ischemia Causes Actin Cytoskeletal Rearrangement and Formation of Gaps in the Endothelial Monolayer that are Prevented by the TLR4 Inhibitor CRX-526

Simulated ischemia resulted in disappearance or peripheral rearrangement of intracellular actin stress fibers and formation of gaps in the HMVEC monolayer (Figure 6). Following simulated reperfusion, the gaps became smaller, and within 4 hours, the cytoskeleton appeared normal and monolayers resumed their original appearance.

In the presence of CRX-526, the area of monolayer gaps was significantly reduced during 
ischemia and monolayers regained confluence more quickly after simulated reperfusion (Figure 6B). The percentage of cells with altered actin cytoskeleton was decreased in monolayers by CRX-526 (Figure 6C). The pattern of alterations in actin stress fibers in HMVECs was also blunted by CRX-526 (Table 1). Cell viability, quantified by LDH assay, was equivalent in controls and treated groups at all time points.

Replacement of medium with Ringer's lactate resulted in a sudden drop in $\mathrm{pH}$ from 7.2 to 6.5, which was reversed when medium was replaced. To address whether gap formation in endothelial cell monolayers was due to changes in $\mathrm{pH}$ alone, we performed experiments in which the $\mathrm{pH}$ of cell culture medium was altered for one hour, either by ventilation of the chamber with $10 \% \mathrm{CO}_{2}(\mathrm{pH} 6.8)$ or by the addition of $\mathrm{HCl}$ to reduce $\mathrm{pH}$ of the medium to 6.5 when ventilated with $100 \% \mathrm{O}_{2}$ or 5.6 when ventilated with $5 \% \mathrm{CO}_{2}$. Altered medium was replaced with normal medium to abruptly restore $\mathrm{pH}$ after one hour. No changes in the integrity of the monolayer were apparent when $\mathrm{pH}$ alone was altered.

TLR4-mediated Alteration of HMVEC Cytoskeleton is Likely Not Due to Paracrine Stimulation by an Endogenous TLR4 Ligand

Ringer's lactate conditioned by HMVECs during 1 hour of warm ischemia did not cause significant gap formation or actin cytoskeletal rearrangement when placed with an equal volume of media on fresh HMVECs (Figure 7A), nor was the conditioned RL able to cause NF- $\mathrm{KB}$ activation in highly sensitive AMs (Figure 7B). Thus, cytoskeletal alteration due to simulated ischemia does not appear to be due to release of a soluble TLR4 ligand in sufficient quantities to be detected by these experiments.

\section{Discussion}

Our studies demonstrate a novel pivotal role for TLR4 as a major upstream effector of 
early edema consequent to reperfusion of ischemic lung. OuJ mice with functioning TLR4 quickly develop substantial edema upon reperfusion after 60 minutes of hilar clamping, due to rapid alveolar flooding. Increased W/D persists at least for 3 hours, when increased alveolar wall thickness and interstitial edema are apparent in inflation-fixed specimens. In contrast, HeJ mice with defective TLR4 develop significantly less edema that resolves quickly, so that within 1 hour of reperfusion, W/D is normal, and inflation-fixed histology is also normal after 3 hours of reperfusion. We confirmed the role of TLR4 in pulmonary edema formation due to IRI by performing experiments in TLR4-/- mice. Increased edema due to functioning TLR4 is apparent within 5 minutes of reperfusion. MyD88-deficient animals developed edema when reperfused similar to TLR4-sufficient OUJ and C57BL/6J mice, the background strain for MyD88-/- and TLR4-/- mice. Thus, MyD88, the downstream adapter protein implicated in activation of signaling cascades by many TLRs including TLR4, does not appear to be involved in development of edema due to IRI.

In addition to a role in edema formation very early after perfusion of ischemic lung, functioning TLR4 mediates early activation of signaling pathways associated with inflammation. Functioning TLR4 resulted in early phosphorylation of p38 (observed during ischemia), early phosphorylation of ERK and JNK, and early activation of NF- $\kappa \mathrm{B}$ following reperfusion. This time course is very similar to MAPK and NF- $\mathrm{B}$ activation following lung transplantation in rats (unpublished work in progress, TME laboratory). TLR4-deficient HeJ mice showed delayed (p38, ERK) or reduced $(\mathrm{NF}-\kappa \mathrm{B}, \mathrm{JNK})$ activation, implying involvement of alternative activation pathways other than TLR4. Delayed activation of p38 and ERK in TLR4-deficient mice was not associated with increased W/D, nor was NF- $\kappa \mathrm{B}$ activation in the right (non-ischemic) lung of TLR4-sufficient mice (Figure 3). In a rat model of in situ left lung IRI, W/D of the right lung is 
also not increased, although MAPKs are activated in the right lung after reperfusion of the left lung (unpublished work in progress, TME laboratory). Thus, although functioning TLR4 is implicated in development of early edema due to IRI, our data suggest that early edema formation due to reperfusion of ischemic lung is not dependent on activation of MAP kinases or $\mathrm{NF}-\kappa \mathrm{B}$, and is not dependent on MyD88.

Our chimeric animal studies show that functioning TLR4 on lung parenchymal cells, not myeloid cells, is critical for early lung edema formation due to IRI. AMs clearly contribute to lung IRI(32) and functioning TLR4 on bone marrow-derived Kuppfer cells contributes to liver IRI assessed biochemically 3 and 6 hours post-reperfusion.(47) However, this study had a different time course, and the two models and outcomes are not necessarily comparable; liver edema was not assessed. Functioning TLR4 on AMs contributed substantially to airway inflammation 4 or 8 hours after LPS inhalation.(18) Depletion of AMs reduced permeability edema in a rat model of lung IRI.(31) However, our data strongly suggest that IRI-induced early pulmonary edema is due to increased capillary leak very early after reperfusion. Our experiments in chimeric mice clearly show this requires functioning TLR4 only on parenchymal lung cells, not myeloid derived AMs.

We used an in vitro model to explore possible mechanisms of rapid edema formation due to IRI, focusing on pulmonary microvascular endothelial cells. Earlier studies demonstrated significantly increased filtration co-efficient and W/D of rat lungs after one hour of ischemia, attributed to endothelial dysfunction,(23) although altered lung epithelial fluid clearance can also contribute to pulmonary edema.(30) Other investigators have employed hypoxia-reoxygenation in cell culture models of IRI, $(37,59)$ but we previously demonstrated lung acidosis to $\mathrm{pH} 6.8$, but no significant hypoxia in rat lungs left in situ at $37^{\circ} \mathrm{C} 1$ hour after cardiac arrest.(28) Thus, 
hypoxia is not a feature of lung ischemia, particularly in lungs inflated with $100 \%$ oxygen, so our cell culture model of IRI accurately reflects in vivo events (although nutrient depletion and development of acidosis would be more gradual in vivo). During simulated ischemia, HMVECs undergo structural alterations with reorganization of actin stress fibers from the center to the periphery of endothelial cells, associated with the development of gaps in the monolayer, not due to increased cell death. Following simulated reperfusion, HMVEC cytoskeletal morphology normalizes, and a confluent monolayer is restored. Although it is difficult to assess the endothelial cell cytoskeleton in vivo, we speculate that the in vitro phenotype is similar to the changes that increase permeability upon reperfusion and cause rapid alveolar flooding in vivo. It takes time for the lung to clear this excess fluid. W/D is still elevated and there is histologic evidence of increased interstitial fluid in TLR4-sufficient mice 3 hours after reperfusion, while lungs from TLR4-deficient mice have a normal histologic appearance (Figure 1B).

Our studies in MyD88-/- mice imply that traditional TLR4-mediated signaling for gene transcription is not related to TLR4-mediated development of edema. Although the TRIF activation pathway may be operational in HMVECs, the time course of actin cytoskeletal alteration in vitro and the time course of activation of MAP kinase and NF- $\mathrm{KB}$ signaling cascades in vivo strongly suggest that TLR4-mediated edema development and alteration of actin cytoskeleton are not related to traditional TLR4-mediated signaling for gene transcription. Additional studies simulating cold IRI in cultured endothelial cells show a similar pattern of NF$\kappa \mathrm{B}$ and MAP kinase activation due to simulated IRI, i.e. activation of $\mathrm{p} 38$ during simulated ischemia, and prominent activation of MAP kinases and NF-kB with simulated reperfusion (submitted for publication). Thus TLR4-mediated actin cytoskeletal alterations during simulated ischemia and TLR4-mediated activation of signaling cascades appear to be separate events that 
occur at different times.

CRX-526, prevented NF- $\mathrm{KB}$ activation in HMVECs exposed to LPS, confirming it is a TLR4 inhibitor. When administered to OuJ mice 1 hour before hilar clamping, CRX-526 prevented edema formation in vivo after 60 min reperfusion. Treatment of HMVECs exposed to simulated IRI in vitro with micromolar doses of CRX-526 resulted in significantly reduced alteration of actin cytoskeleton, significantly decreased gap formation, and quicker recovery. Thus, through mediation of endothelial actin cytoskeleton, TLR4 may be an important effector of IRI-induced edema in humans, and the TLR4 receptor may be a promising target for pharmacologic intervention to mitigate IRI and other forms of acute lung injury. Pre-treatment of mice with eritoran, another TLR4 inhibitor, reduced myocardial infarction size in a murine model of cardiac IRI.(41) It is possible that CRX-526 may have effects on other receptors or pathways besides TLR4, but our in vivo data in HeJ and TLR4-/- mice clearly show that functional TLR4 substantially contributes to IRI-induced pulmonary edema.

Does a released ligand, such as HSP-70, a saturated fatty acid(29) or hyaluronan fragments $(22,46)$ explain how TLR4 mediates edema due to IRI? Our in vitro experiments failed to demonstrate a soluble ligand capable of altering HMVEC shape in cell culture or activating NF- $\kappa \mathrm{B}$ in highly sensitive AMs. Our experiments do not rule out the possibility of release of a ligand that binds quickly and avidly to TLR4 or other receptors and is not present in sufficient quantity in conditioned media (Ringer's lactate removed from cells that experienced cytoskeletal alteration) to activate TLR4 on AMs or alter HMVEC actin cytoskeleton. A TLR4 ligand released into the circulation following reperfusion of the ischemic left lung may explain why NF- $\kappa$ B activation was apparent in the contralateral lungs (Figure 3), but NF- $\kappa$ B activation was not associated with development of edema in the right lungs. It is difficult to understand 
which TLR4 ligand would be involved in our cell culture experiment of simulated warm IRI. Why should replacing cell culture media with pyrogen-free commercial Ringer's lactate release a TLR4 ligand? And if a TLR4 ligand were released in vivo during ischemia, then one would expect to see at least activation of NF- $\mathrm{KB}$ at 0 min reperfusion in Figure 2. Thus, our in vitro results suggest that TLR4-mediated alteration in endothelial morphology during ischemia may be independent of soluble TLR4 ligand released by endothelial cells.

TLR4 has been implicated as a contributor to several other forms of acute lung injury, including ozone-induced increased permeability(27) and inhaled LPS.(17) Paradoxically, TLR4/- mice are more susceptible to hyperoxia than wild type mice.(60) In IRI models, until now other investigators have studied events occurring hours or days after reperfusion, based on the assumption that any effects of TLR4 were mainly related to transcriptional regulation. TLR4deficient mice have reduced myocardial infarction size 24 hours after one hour ligation of the left anterior descending coronary artery(35) and reduced levels of aspartate aminotransferase 1 and 3 hours after reperfusion of liver lobes rendered ischemic for 45 minutes.(53) TLRs were implicated in a rat model of renal IRI, but the earliest studies were performed 24 hours after reperfusion.(25) TLR4 protein and mRNA were elevated for days after renal IRI, and TLR4-/- as well as MyD88-/- animals had less renal dysfunction and less histologic evidence of IRI 24 hours after reperfusion.(52) TLR4 contributes to markers of inflammation in a murine cardiac transplant model.(24) During the course of our studies, Shimamoto et al reported that TLR4-/mice experienced less increased permeability index following 3 hours of reperfusion using a similar model of lung IRI.(42) TLRs have multiple roles including both pattern formation during embryogenesis and recognition of pathogen-associated molecular patterns (PAMP).(21, 44) TLR4 has been implicated in other types of non-infectious inflammatory conditions. $(31,33)$ 
Other TLRs are involved in lung injury. Jiang et al showed reduced bleomycin-induced lung injury in double knockout TLR4/TLR2-/- mice.(22) We have begun to study IRI in TLR2-/mice; these animals develop less edema than C57BL/6J mice (ongoing unpublished work, Egan laboratory). Our study is the first to show effects of TLR4 so early after injury, and the first to implicate TLR4 in early development of edema due to IRI.

Our results are most consistent with TLR4 regulation of pulmonary microvascular endothelial barrier function in lung IRI by TLR4-mediated microvascular endothelial cell cytoskeletal alteration contributing to rapid development of edema when ischemic lung is reperfused. This is a novel and potentially very important role for the TLR4 receptor. Gong et al showed knockdown of TLR4 in HMVECs prevented increased permeability after 6 hours exposure to LPS, and TLR4-associated activation of Src protein tyrosine kinases (PTKs).(15) Our cell culture studies did not address whether MyD88 or the TRIF pathway downstream of TLR4 was involved in endothelial cytoskeletal alteration in response to ischemia. However our observations that edema due to IRI occurs in MyD88-/- mice coupled with the absence of the TRIF pathway in murine endothelial cells(16) and our data that edema due to IRI occurs irrespective of MAPK and NF- $\mathrm{KB}$ activation, suggest that edema mediated by TLR4 occurs independent of TLR4-mediated transcriptional events. The absence of the TRIF pathway has not been documented in human endothelial cells to our knowledge. In addition to modulating the Src PTKs, we postulate that TLR4 may be interacting through RhoA and Rac to modify actin cytoskeleton. Several studies have observed changes in the actin cytoskeleton in response to TLR ligands such as LPS, $(48,49)$ a role for RhoA downstream of LPS signaling $(13,43)$ and Rac activation has been observed.(51)

Two phases (early and late) have been described in many forms of acute lung injury, 
dating back to early studies of the effect of endotoxin infusion (36) or activated complement.(12) Our study clearly implicates TLR4 on pulmonary microvascular endothelial cells for early development of lung edema due to IRI, and through downstream signaling, TLR4 likely contributes to the later phase as well. Thus, TLR4 may be an important link between the two phases of acute lung injury and may have two distinct roles: mediating alteration of endothelial actin cytoskeleton, and mediating gene transcription through MyD88 and TRIF/TRAM adapter proteins that have downstream effects on signal transduction pathways including MAP kinases, NF- $\kappa \mathrm{B}$, and possibly other signaling pathways. The point missense mutation of TLR4 in HeJ mice affects an intracellular portion of the TLR4 receptor at the interface with the MyD88 adapter, disrupting its recruitment, accounting for inability of the $\mathrm{HeJ}$ strain to respond to LPS.(55) Perhaps this mutation also reduces endothelial cytoskeletal alteration in response to ischemia, prompting us to speculate that this may also be the site of interaction of TLR4 with the endothelial cytoskeleton. The endothelial cytoskeleton, particularly actin stress fibers, plays a critical role in regulation of pulmonary vascular permeability.(7) The cytoskeleton may also function as an intracellular communication system or signaling scaffold.(19)

An alternative explanation for our findings is that the absence of functional TLR4 alters the phenotype of endothelial cells in some way that renders them less susceptible to ischemiainduced cytoskeletal alteration. Zhang et al showed the TLR4-/- mice tend to develop emphysema as they age, and noted that TLR4-/- mice have a different phenotype compared to wild type mice, in that they appear to have decreased anti-oxidant capacity and increased oxidant burden. This was attributed to increased Nox3 expression in lung tissue and endothelial cells from TLR4-/- mice.(58) Thus, although a direct link between TLR4 and the cytoskeleton seems likely, it is also possible that indirect effects of non-functioning TLR4 may alter the phenotype of 
the cells contributing to cytoskeletal disruption due to IRI.

Irrespective of the mechanism, our findings have important clinical implications, not only for the opportunity to modify IRI for recipients of lung or other organ transplants, but because many types of acute lung injury have strikingly similar phenotypes. Longer follow-up studies are necessary to understand whether TLR4 inhibition is beneficial or impairs lung integrity.

TLR4/TLR2-/- mice had reduced markers of inflammation in BAL fluid early after bleomycin lung injury, but suffered increased later mortality due to apoptosis in the lung.(22) If transient TLR4 inhibition could safely reduce IRI, then this might benefit all organ transplant recipients, and facilitate transplantation of lungs from non-heart-beating donors. This could provide lung transplants for thousands of patients with end-stage lung disease. Administration of a TLR4 inhibitor, either via the airway to a $\operatorname{NHBD}(45)$, or via the pulmonary artery in an ex-vivo perfusion circuit, $(10,20,50)$ or both, might mitigate IRI when lungs retrieved from NHBDs are subsequently transplanted. 


\section{Acknowledgments}

The authors acknowledge the technical assistance of Mauricio Rojas (microsurgery), Kimberlie Burns (histology), Leigh Thorne and Nana Feinberg (immunohistochemical staining); and Clarence E. Davis (statistics); reviews by Philip Bromberg and Richard Boucher; and editorial assistance of Margaret Alford Cloud. CRX-526 was provided by GlaxoSmithKline under a Material Transfer Agreement.

\section{Grants}

This work was supported by Cystic Fibrosis Foundation grants EGAN00P0, EGAN02P0 and EGAN06P0 (TME) and NIH grants R01 HL63159 (TME), RO1 HL080322 (SHR), PO1 HL45100 and PO1HL080166 (KB).

\section{Disclosures}

UNC has filed a provisional patent on the discovery that CRX-526 prevents IRI-induced pulmonary edema and reduces actin cytoskeletal arrangement and gap formation in cultured HMVECs subjected to simulated IRI. The authors have nothing to disclose. 


\section{References}

1. Casiraghi M, Abano J, Burridge K, Randell S, and Egan T. Toll-like receptor-4 (TLR4) inhibition reduces actin cytoskeletal re-arrangement and gap formation in cultured human pulmonary microvascular endothelial cells (HMVECs) subjected to simulated warm ischemia-reperfusion injury (IRI). (Abstract) Journal of Heart and Lung Transplantation 27: S214-215, 2008.

2. Cho HY and Kleeberger SR. Genetic mechanisms of susceptibility to oxidative lung injury in mice. Free Radic Biol Med 42: 433-445, 2007.

3. Chow JC, Young DW, Golenbock DT, Christ WJ, and Gusovsky F. Toll-like receptor-4 mediates lipopolysaccharide-induced signal transduction. J Biol Chem 274: 1068910692, 1999.

4. de Groot $\mathbf{H}$ and Rauen U. Ischemia-reperfusion injury: processes in pathogenetic networks: a review. Transplant Proc 39: 481-484, 2007.

5. de Perrot M, Liu M, Waddell TK, and Keshavjee S. Ischemia-reperfusion-induced lung injury. Am J Respir Crit Care Med 167: 490-511, 2003.

\section{Dodd-o JM, Hristopoulos ML, Welsh-Servinsky LE, Tankersley CG, and Pearse}

DB. Strain-specific differences in sensitivity to ischemia-reperfusion lung injury in mice. $J \mathrm{Appl}$ Physiol 100: 1590-1595, 2006.

7. Dudek SM and Garcia JG. Cytoskeletal regulation of pulmonary vascular permeability. J Appl Physiol 91: 1487-1500, 2001.

8. Egan T. Non-heart-beating donors in thoracic transplantation. J Heart Lung Transplant 23: 3-10, 2004. 
9. Egan T, Thomas Y, Gibson D, Funkhouser W, Ciriaco P, Kiser A, Sadoff J, Bleiweis

M, and Davis C. Trigger for intercellular adhesion molecule-1 expression in rat lungs transplanted from non-heart-beating donors. Ann Thorac Surg 77: 1048-1055, 2004.

10. Egan TM, Haithcock JA, Nicotra WA, Koukoulis G, Inokawa H, Sevala M, Molina PL, Funkhouser WK, and Mattice BJ. Ex-vivo evaluation of human lungs for transplant suitability. Ann Thorac Surg 81: 1205-1213, 2006.

11. Egan TM, Lambert Jr CJ, Reddick RL, Ulicny Jr KS, Keagy BA, and Wilcox BR. A strategy to increase the donor pool: the use of cadaver lungs for transplantation. Ann Thorac Surg 52: 1113-1121, 1991.

12. Egan TM, Saunders NR, Luk SC, and Cooper JD. Complement-mediated pulmonary edema in sheep. J Surg Res 45: 204-214, 1988.

13. Essler M, Staddon JM, Weber PC, and Aepfelbacher M. Cyclic AMP blocks bacterial lipopolysaccharide-induced myosin light chain phosphorylation in endothelial cells through inhibition of Rho/Rho kinase signaling. J Immunol 164: 6543-6549, 2000.

\section{Fort MM, Mozaffarian A, Stover AG, Correia Jda S, Johnson DA, Crane RT,} Ulevitch RJ, Persing DH, Bielefeldt-Ohmann H, Probst P, Jeffery E, Fling SP, and Hershberg RM. A synthetic TLR4 antagonist has anti-inflammatory effects in two murine models of inflammatory bowel disease. J Immunol 174: 6416-6423, 2005.

\section{Gong P, Angelini DJ, Yang S, Xia G, Cross AS, Mann D, Bannerman DD, Vogel SN,} and Goldblum SE. TLR4 signaling is coupled to SRC family kinase activation, tyrosine phosphorylation of zonula adherens proteins, and opening of the paracellular pathway in human lung microvascular endothelia. J Biol Chem 283: 13437-13449, 2008. 
16. Harari OA, Alcaide P, Ahl D, Luscinskas FW, and Liao JK. Absence of TRAM restricts Toll-like receptor 4 signaling in vascular endothelial cells to the MyD88 pathway. Circ Res 98: 1134-1140, 2006.

17. Hollingsworth JW, 2nd, Cook DN, Brass DM, Walker JK, Morgan DL, Foster WM, and Schwartz DA. The role of Toll-like receptor 4 in environmental airway injury in mice. $A m J$ Respir Crit Care Med 170: 126-132, 2004.

18. Hollingsworth JW, Chen BJ, Brass DM, Berman K, Gunn MD, Cook DN, and Schwartz DA. The Critical Role of Hematopoietic Cells in Lipopolysaccharide-induced Airway Inflammation. Am J Respir Crit Care Med 171: 806-813, 2005.

19. Ingber DE. Cellular mechanotransduction: putting all the pieces together again. Faseb $J$ 20: 811-827, 2006.

20. Inokawa H, Sevala M, Funkhouser WK, and Egan TM. Ex-vivo perfusion and ventilation of rat lungs from non-heart-beating donors before transplant. Ann Thorac Surg 82: 1219-1225, 2006.

21. Janssens S and Beyaert R. Role of Toll-like receptors in pathogen recognition. Clin Microbiol Rev 16: 637-646, 2003.

22. Jiang D, Liang J, Fan J, Yu S, Chen S, Luo Y, Prestwich GD, Mascarenhas MM, Garg HG, Quinn DA, Homer RJ, Goldstein DR, Bucala R, Lee PJ, Medzhitov R, and Noble PW. Regulation of lung injury and repair by Toll-like receptors and hyaluronan. Nat Med 11: 1173-1179, 2005.

23. Jones DR, Becker RM, Hoffmann SC, Lemasters JJ, and Egan TM. When does the lung die?--Kfc, cell viability, and adenine nucleotide changes in the circulation-arrested rat lung. J Appl Physiol 83: 247-252, 1997. 


\section{Kaczorowski DJ, Nakao A, Mollen KP, Vallabhaneni R, Sugimoto R, Kohmoto J,} Tobita K, Zuckerbraun BS, McCurry KR, Murase N, and Billiar TR. Toll-like receptor 4 mediates the early inflammatory response after cold ischemia/reperfusion. Transplantation 84 : 1279-1287, 2007.

25. Kim BS, Lim SW, Li C, Kim JS, Sun BK, Ahn KO, Han SW, Kim J, and Yang CW. Ischemia-reperfusion injury activates innate immunity in rat kidneys. Transplantation 79: 1370$1377,2005$.

26. King RC, Binns OAR, Rodriguez F, Kanithanon RC, Daniel TM, Spotnitz WD, Tribble CG, and Kron IL. Reperfusion injury significantly impacts clinical outcome after pulmonary transplantation. Ann Thorac Surg 69: 1681-1685, 2000.

27. Kleeberger SR, Reddy SP, Zhang LY, Cho HY, and Jedlicka AE. Toll-like receptor 4 mediates ozone-induced murine lung hyperpermeability via inducible nitric oxide synthase. $A m J$ Physiol Lung Cell Mol Physiol 280: L326-333, 2001.

28. Koukoulis G, Caldwell R, Inokawa H, Button B, Sevala M, Lyles JD, Takashima S, Blackwell J, Randell SH, and Egan TM. Trends in lung pH and PO2 after circulatory arrest: implications for non-heart-beating donors and cell culture models of lung ischemia-reperfusion injury. J Heart Lung Transplant 24: 2218-2225, 2005.

29. Lee JY, Sohn KH, Rhee SH, and Hwang D. Saturated fatty acids, but not unsaturated fatty acids, induce the expression of cyclooxygenase-2 mediated through Toll-like receptor 4. $J$ Biol Chem 276: 16683-16689, 2001.

30. Matthay MA, Robriquet L, and Fang X. Alveolar epithelium: role in lung fluid balance and acute lung injury. Proc Am Thorac Soc 2: 206-213, 2005. 
31. Mollen KP, Anand RJ, Tsung A, Prince JM, Levy RM, and Billiar TR. Emerging paradigm: toll-like receptor 4-sentinel for the detection of tissue damage. Shock 26: 430-437, 2006.

\section{Naidu BV, Krishnadasan B, Farivar AS, Woolley SM, Thomas R, Van Rooijen N,} Verrier ED, and Mulligan MS. Early activation of the alveolar macrophage is critical to the development of lung ischemia-reperfusion injury. J Thorac Cardiovasc Surg 126: 200-207, 2003.

33. O'Neill LA. TLRs play good cop, bad cop in the lung. Nat Med 11: 1161-1162, 2005.

34. O'Neill LA and Bowie AG. The family of five: TIR-domain-containing adaptors in Tolllike receptor signalling. Nat Rev Immunol 7: 353-364, 2007.

35. Oyama J, Blais C, Jr., Liu X, Pu M, Kobzik L, Kelly RA, and Bourcier T. Reduced myocardial ischemia-reperfusion injury in toll-like receptor 4-deficient mice. Circulation 109: 784-789, 2004.

36. Parker RE and Brigham KL. Effects of endotoxemia on pulmonary vascular resistances in unanesthetized sheep. J Appl Physiol 63: 1058-1062, 1987.

37. Powell CS and Jackson RM. Mitochondrial complex I, aconitase, and succinate dehydrogenase during hypoxia-reoxygenation: modulation of enzyme activities by MnSOD. $\mathrm{Am}$ J Physiol Lung Cell Mol Physiol 285: L189-198, 2003.

\section{Sanlioglu S, Williams CM, Samavati L, Butler NS, Wang G, McCray PB, Jr.,} Ritchie TC, Hunninghake GW, Zandi E, and Engelhardt JF. Lipopolysaccharide induces Rac1-dependent reactive oxygen species formation and coordinates tumor necrosis factor-alpha secretion through IKK regulation of NF-kappa B. J Biol Chem 276: 30188-30198, 2001. 
39. Saria A and Lundberg JM. Evans blue fluorescence: quantitative and morphological evaluation of vascular permeability in animal tissues. J Neurosci Methods 8: 41-49, 1983.

40. Schwaller J, Frantsve J, Aster J, Williams IR, Tomasson MH, Ross TS, Peeters P, Van Rompaey L, Van Etten RA, Ilaria R, Jr., Marynen P, and Gilliland DG.

Transformation of hematopoietic cell lines to growth-factor independence and induction of a fatal myelo- and lymphoproliferative disease in mice by retrovirally transduced TEL/JAK2 fusion genes. Embo J 17: 5321-5333, 1998.

41. Shimamoto A, Chong AJ, Yada M, Shomura S, Takayama H, Fleisig AJ, Agnew ML, Hampton CR, Rothnie CL, Spring DJ, Pohlman TH, Shimpo H, and Verrier ED. Inhibition of Toll-like receptor 4 with eritoran attenuates myocardial ischemia-reperfusion injury. Circulation 114: I270-274, 2006.

42. Shimamoto A, Pohlman TH, Shomura S, Tarukawa T, Takao M, and Shimpo H. Toll-like receptor 4 mediates lung ischemia-reperfusion injury. Ann Thorac Surg 82: 2017-2023, 2006.

43. Shimizu S, Tahara M, Ogata S, Hashimoto K, Morishige K, Tasaka K, and Murata Y. Involvement of nuclear factor-kB activation through RhoA/Rho-kinase pathway in LPSinduced IL-8 production in human cervical stromal cells. Mol Hum Reprod 13: 181-187, 2007. 44. Sioud M, Floisand Y, Forfang L, and Lund-Johansen F. Signaling through toll-like receptor $7 / 8$ induces the differentiation of human bone marrow $\mathrm{CD} 34+$ progenitor cells along the myeloid lineage. J Mol Biol 364: 945-954, 2006.

45. Takashima S, Koukoulis G, Inokawa H, Sevala M, and Egan TM. Inhaled nitric oxide reduces ischemia-reperfusion injury in rat lungs from non-heart-beating donors. $J$ Thorac Cardiovasc Surg 132: 132-139, 2006. 
46. Taylor KR, Yamasaki K, Radek KA, Nardo AD, Goodarzi H, Golenbock D, Beutler B, and Gallo RL. Recognition of Hyaluronan Released in Sterile Injury Involves a Unique Receptor Complex Dependent on Toll-like Receptor 4, CD44, and MD-2. J Biol Chem 282: 18265-18275, 2007.

\section{Tsung A, Hoffman RA, Izuishi K, Critchlow ND, Nakao A, Chan MH, Lotze MT,}

Geller DA, and Billiar TR. Hepatic ischemia/reperfusion injury involves functional TLR4 signaling in nonparenchymal cells. J Immunol 175: 7661-7668, 2005.

48. Watts C, Zaru R, Prescott AR, Wallin RP, and West MA. Proximal effects of Tolllike receptor activation in dendritic cells. Curr Opin Immunol 19: 73-78, 2007.

49. West MA, Wallin RP, Matthews SP, Svensson HG, Zaru R, Ljunggren HG, Prescott AR, and Watts C. Enhanced dendritic cell antigen capture via toll-like receptor-induced actin remodeling. Science 305: 1153-1157, 2004.

50. Wierup P, Haraldsson A, Nilsson F, Pierre L, Schersten H, Silverborn M, Sjoberg T, Westfeldt U, and Steen S. Ex vivo evaluation of nonacceptable donor lungs. Ann Thorac Surg 81: 460-466, 2006.

51. Woo CH and Kim JH. Rac GTPase activity is essential for lipopolysaccharide signaling to extracellular signal-regulated kinase and p38 MAP kinase activation in rat-2 fibroblasts. Mol Cells 13: 470-475, 2002.

52. Wu H, Chen G, Wyburn KR, Yin J, Bertolino P, Eris JM, Alexander SI, Sharland AF, and Chadban SJ. TLR4 activation mediates kidney ischemia/reperfusion injury. J Clin Invest 117: 2847-2859, 2007. 
53. Wu HS, Zhang JX, Wang L, Tian Y, Wang H, and Rotstein O. Toll-like receptor 4 involvement in hepatic ischemia/reperfusion injury in mice. Hepatobiliary Pancreat Dis Int 3: 250-253, 2004.

54. Wu Q, Lu Z, Verghese MW, and Randell SH. Airway epithelial cell tolerance to Pseudomonas aeruginosa. Respir Res 6: 26, 2005.

55. Xu Y, Tao X, Shen B, Horng T, Medzhitov R, Manley JL, and Tong L. Structural basis for signal transduction by the Toll/interleukin-1 receptor domains. Nature 408: 111-115, 2000 .

56. Zanotti G, Berlin H, Sevala M, Smyth S, Randell S, and Egan T. Toll-like receptor 4 (TLR4) on lung parenchymal cells: a critical mediator of ischemia-reperfusion injury (IRI) (Abstract). Proc Am Thorac Soc 3: A685, 2006.

57. Zanotti G, Randell S, Funkhouser W, Sevala M, and Egan T. Critical role of Toll-like receptor (TLR) 4 in lung ischemia-reperfusion injury (IRI) (Abstract). J Heart Lung Transplant 25: S54, 2006.

58. Zhang X, Shan P, Jiang G, Cohn L, and Lee PJ. Toll-like receptor 4 deficiency causes pulmonary emphysema. J Clin Invest 116: 3050-3059, 2006.

59. Zhang X, Shan P, Otterbein LE, Alam J, Flavell RA, Davis RJ, Choi AM, and Lee PJ. Carbon monoxide inhibition of apoptosis during ischemia-reperfusion lung injury is dependent on the p38 mitogen-activated protein kinase pathway and involves caspase 3. J Biol Chem 278: 1248-1258, 2003.

60. Zhang X, Shan P, Qureshi S, Homer R, Medzhitov R, Noble PW, and Lee PJ. Cutting Edge: TLR4 Deficiency Confers Susceptibility to Lethal Oxidant Lung Injury. $J$ Immunol 175: 4834-4838, 2005. 
Table 1

\begin{tabular}{|c|c|c|}
\hline Time & & \\
\hline Control & $\begin{array}{l}\text { Actin a bit more prominent at the periphery, } \\
\text { crossing the cell centers. Essentially normal }\end{array}$ & $\begin{array}{l}\text { but in most cells there are stress fibers } \\
\text { pattern for ECs. }\end{array}$ \\
\hline & Vehicle & CRX-526 \\
\hline $\begin{array}{l}15 \mathrm{~min} \\
\mathrm{WI}\end{array}$ & $\begin{array}{l}\text { Stress fibers across the middle of the cells } \\
\text { look more prominent, and the edges are } \\
\text { well defined by peripheral actin. }\end{array}$ & $\begin{array}{l}\text { Actin a bit more prominent at the } \\
\text { periphery, but there are still stress } \\
\text { fibers crossing the cell centers. }\end{array}$ \\
\hline 1 hr WI & $\begin{array}{l}\text { A few gaps are present. Actin stress fibers } \\
\text { are mainly peripheral. }\end{array}$ & $\begin{array}{l}\text { Actin is less pronounced and is more } \\
\text { peripheral. Possibly some ruffling } \\
\text { going on at the cell edges? There may } \\
\text { be some gaps. }\end{array}$ \\
\hline $\begin{array}{l}15 \mathrm{~min} \\
\text { rep }\end{array}$ & $\begin{array}{l}\text { Actin staining looks more peripheral } \\
\text { around the cell-cell borders. The overall } \\
\text { cell appearance is more "cobblestone". }\end{array}$ & $\begin{array}{l}\text { Stress fibers look prominent and are } \\
\text { crossing the cell centers. }\end{array}$ \\
\hline 1 hr rep & $\begin{array}{l}\text { Actin stress fibers crossing the cell centers; } \\
\text { in some frames the actin looks quite } \\
\text { cobblestone. }\end{array}$ & Stress fibers are prominent. \\
\hline 4 hr rep & $\begin{array}{l}\text { Actin appears a little disorganized and } \\
\text { more peripheral; some variability between } \\
\text { the panels. }\end{array}$ & $\begin{array}{l}\text { Very prominent stress fibers crossing } \\
\text { the cell centers. Less at the periphery. } \\
\text { Fairly normal appearance. }\end{array}$ \\
\hline 24 hr rep & $\begin{array}{l}\text { Actin a bit more prominent at the } \\
\text { periphery, but essentially normal. }\end{array}$ & $\begin{array}{l}\text { Actin is more pronounced at the cell } \\
\text { periphery. }\end{array}$ \\
\hline
\end{tabular}

Six photographs of HMVECs stained with phalloidin (400X) at each time point were randomly chosen and grouped in Powerpoint slides. No times were identified. The photos were studied and assessed by a cytoskeletal expert (KB) in a masked manner. Comments about the quality and location of actin stress fibers in HMVECs at designated time points in the experiment are displayed . Control = normal HMVECs in cell culture media; $\mathrm{WI}=$ warm ischemia $($ media replaced with Ringer's lactate); rep = simulated reperfusion (Ringer's lactate replaced with cell culture media). 


\section{Figure Legends}

Figure 1. TLR4 is a key mediator of pulmonary edema ( $\uparrow \mathrm{W} / \mathrm{D})$ due to IRI.

A. Ischemia alone (0 hr reperfusion) caused no increase in W/D. Following reperfusion, less edema develops in TLR4-deficient mice (HeJ), and is resolved by 1 hour, but edema persists for

$3 \mathrm{hrs}$ in TLR4-sufficient mice (OuJ). LL=left lung; $\mathrm{RL}=$ right lung. ${ }^{*} \mathrm{p}<0.05,+\mathrm{p}<0.001$ compared to respective Controls. $\mathrm{p}<0.001$ OUJ LL compared to other lungs at 15, $30 \mathrm{~min}, 1$ and $3 \mathrm{hr}$ reperfusion. n=6/group. ANOVA with Tukey's post hoc.

B. Inflation fixed (25 cm H2O) left lungs retrieved after 1 hour hilar clamp and 3 hours of reperfusion show increased interstitial edema in peribronchial and perivascular spaces in TLR4sufficient mice (OuJ) compared to TLR4-deficient mice (HeJ) (red arrows, upper panel x 40), and thicker alveolar walls (black arrows (lower panel x 200). Representative of 4 specimens. C. Despite significant difference in W/D following $60 \mathrm{~min}$ reperfusion, there is no interstitial peribronchial/ perivascular edema in TLR4-sufficient (OuJ) and TLR4-deficient (HeJ) mice (upper panel x40), and no alveolar wall thickening (lower panel x 200). Representative of four specimens. These inflation fixed sections look identical to control specimens (not shown). D. Evans blue dye accumulation in left lungs retrieved after one hour of hilar clamping and one hour of reperfusion supports the assumption that alveolar flooding is the reason for $\uparrow W / D$ in TLR4-sufficient mice (OuJ) compared to TLR4-deficient mice (HeJ) * $p<0.05$ unpaired t test; $\ddagger$ $\mathrm{p}<0.05$ paired t test.

E. Left lungs retrieved after one hour of hilar clamping and one hour of reperfusion from MyD88-deficient mice $(n=5)$ develop the same increase in W/D as TLR4-sufficient (OuJ) mice. $(n=6)$, and C57BL/6J mice $(n=6)$, their background strain. 
F. TLR4-/- mice develop significantly less edema than the background strain C57BL/6J mice after one hour left hilar clamp and reperfusion for $5,15,30,60$ or 180 minutes $(n=3$ at 5, 15, 30, 180 min, $\mathrm{n}=6$ otherwise). ${ }^{*} \mathrm{p}<0.05, \dagger \mathrm{p}<0.01,+\mathrm{p}<0.001$ ANOVA with Tukey’s post hoc compared to respective Controls; $\S \mathrm{p}<0.05$ compared to other lungs at $5 \mathrm{~min}$. For all other reperfusion times, $\mathrm{p}<0.001$ BL6 LL compared to all others, ANOVA with Tukey's post hoc. Although TLR4-/- left lungs gain some weight with time, they are not different compared to right lungs of either strain at any time point except at $1 \mathrm{hr}$ reperfusion $(\mathrm{p}<0.05)$. This small weight gain with time may be due to strain differences in susceptibility to lung injury (see text).

Figure 2. Activation of MAP kinases and NF- $\mathrm{B}$ due to IRI differs between strains.

A. Protein extracted from left lungs rendered ischemic $x 1$ hour, then reperfused for 0,15,30, 60 or 180 minutes. Activation of JNK, ERK, p38 and NF- $\kappa \mathrm{B}$ is apparent early in TLR4-sufficient mice $(\mathrm{OuJ})$, whereas TLR4-deficient mice (HeJ) have minimal or no degradation of JNK, reduced activation of ERK until 180 minutes, and very delayed activation of $\mathrm{p} 38$. I $\mathrm{B} \alpha$ degradation occurs earlier in OuJ mice and later (180 minutes) in HeJ mice. $\mathrm{n}=4$ each of HeJ and OUJ strains; Controls - 2 HeJ, 2 OuJ mice sacrificed and lungs retrieved expeditiously. Protein from controls were placed on each gel for each time point to allow comparison with normal lung for each time point.

B. Quantification of intensity by laser scanning. Phospho/total MAPKs and I $\mathrm{B} \alpha / \beta$-actin were normalized by dividing each ratio by the mean ratio for controls. This makes each control=1.0 with variability among the different control samples represented by error bars. mean \pm SEM. p46 $\&$ p54 JNK, and p44 \& p42 ERK have similar patterns and p values. $* p<0.05 ; \uparrow p<0.01$; $\neq \mathrm{p}<0.001$ compared to Controls by ANOVA with Tukey’s Honest Significant Difference for 
multiple comparisons.

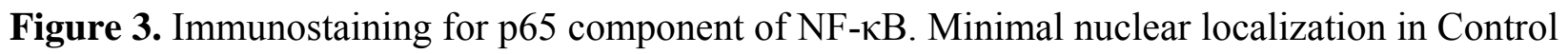
(freshly sacrificed), with marked nuclear staining (3+) in 60 min reperfused samples in TLR4sufficient (OuJ) mice compared to TLR4-deficient (HeJ) strain where staining was graded 1-2+. Immunostaining intensity complemented $\mathrm{I} \kappa \mathrm{B} \alpha$ degradation (Figure 2), except that I $\mathrm{B} \alpha$ levels appear equivalent in $\mathrm{HeJ}$ and $\mathrm{OuJ}$ strains at 180 min reperfusion despite more p65 staining in $\mathrm{OuJ}$ animals at 180 min reperfusion. We interpret this to mean some recovery of $\mathrm{I} \kappa \mathrm{B} \alpha$ protein in OuJ mice180 minutes post-reperfusion. Curiously, p65 staining was the same for right and left lungs in both strains, implying equivalent NF- $\kappa$ B activation in both lungs following reperfusion of the left ischemic lung.

Figure 4. Functioning TLR4 on lung parenchymal cells is necessary for development of edema due to IRI. $\mathrm{P}=$ parenchymal cells, $\mathrm{M}=$ marrow-derived cells, $+=$ intact TLR4 (OuJ) - = nonfunctional TLR4 (HeJ).

A. AMs retrieved by BAL were infected with Ad.NFאBLuc and Ad.CMV-LacZ, then incubated with PBS or LPS $1 \mu \mathrm{g} / \mathrm{ml}$. Firefly luciferase / $\beta$-galactosidase activity shows complete replacement of recipient marrow from either $\mathrm{HeJ}$ strain $(\mathrm{P}+\mathrm{M}-)$ or $\mathrm{OuJ}$ strain $(\mathrm{P}-\mathrm{M}+)$. AMs retrieved from non-irradiated $\mathrm{HeJ} \& \mathrm{OuJ}$ mice served as controls. LPS stimulation resulted in $\sim 60$-fold increase in luciferase activity in both native OuJ AMs and in AM's retrieved from chimeric strain $\mathrm{P}-\mathrm{M}+. \mathrm{n}=4$ experiments/group, $\mathrm{p}<0.0001$. AMs retrieved from irradiated mice reconstituted with same strain marrow behaved in the same manner (data not shown). B. Functioning TLR4 on parenchymal cells (P) is necessary for development of edema after 3 
hours IRI. P+M- chimeras developed significant increase in W/D. However, even if AMs had functioning TLR4 (P-M+) W/D was not elevated. Thus, functioning TLR4 on AMs is not sufficient for development of edema, but may amplify edema in mice with functioning TLR4 on lung parenchymal cells; W/D was slightly higher in $\mathrm{P}+\mathrm{M}+$ animals compared to $\mathrm{P}+\mathrm{M}-$, but the difference was not significant. $\mathrm{n}=5$ /group * $\mathrm{p}<0.05, \dagger \mathrm{p}<0.01$ compared to W/D of P- left lungs (ANOVA with Tukey's HSD).

C. Chimeras with restored bone marrow $(\mathrm{P}-\mathrm{M}-, \mathrm{P}+\mathrm{M}+)$ had the same $\mathrm{W} / \mathrm{D}$ as the intact strains (OuJ, HeJ) demonstrating that lethal radiation and BMT had no effect on development of edema due to IRI.

Figure 5. A competitive inhibitor of TLR4 (CRX-526) prevents lung edema due to IRI and TLR4-mediated activation of NF- $\kappa \mathrm{B}$.

A. W/D of left lungs of OuJ mice pre-treated with vehicle or $10 \mu \mathrm{g}$ CRX-526 in $200 \mu \mathrm{l}$ normal saline administered over 30 minutes, 30 minutes before left hilar clamping for 1 hour and 1 hour reperfusion. Mice pre-treated with CRX-526 had the same W/D as HeJ mice 1 hour postreperfusion in Figure 1A. $\mathrm{n}=5$ /group, ${ }^{*} \mathrm{p}=0.0014$ compared to $\mathrm{R}$ lung of same animal by paired $\mathrm{t}$ test; $\mathrm{p}=0.0023$ compared to $\mathrm{L}$ lung of mice pre-treated with CRX-526 by unpaired $\mathrm{t}$ test. B. Concentrations of CRX-526 from $100 \mu \mathrm{g} / \mathrm{ml}$ to $0.1 \mu \mathrm{g} / \mathrm{ml}$ successfully inhibited NF- $\mathrm{kB}$ activation (based on luciferase/ $\beta$-gal activity) following stimulation of HMVECs in 96 well plates with LPS (10 or $5 \mathrm{ng} / \mathrm{ml}$ ), but CRX-526 had no impact on TNF stimulation of NF- $\mathrm{kB}$ activation (black bars). $\mathrm{n}=4$ /group, ${ }^{*} \mathrm{p}<0.05$ compared to other values at same time point by ANOVA. 
Figure 6. Simulated warm ischemia without hypoxia causes actin cytoskeletal rearrangement and formation of gaps in the human pulmonary microvascular endothelial monolayer.

A. HMVECs grown to confluence on P30 dishes with integral cover slips were incubated with 1 $\mu \mathrm{g} / \mathrm{ml}$ CRX-526 or vehicle, ventilated with 95\%O2/5\%CO2. Media was replaced with warm $\left(37^{\circ} \mathrm{C}\right) \mathrm{RL}$ and ventilated with $100 \% \mathrm{O} 2$ to simulate warm ischemia. One hour later, $\mathrm{RL}$ was replaced with warm cell culture media, and chambers were ventilated with $95 \%$ room air $/ 5 \% \mathrm{CO} 2$ to simulate reperfusion. During simulated warm ischemia, actin stress fibers disappeared or became more peripheral in the cells (black arrows), associated with formation of gaps in the endothelial monolayer (white arrows). Four hours after simulated reperfusion (240 min rep) and 24 hours after simulated reperfusion (not shown), monolayers were confluent and actin cytoskeleton pattern was similar to controls. Gaps in the monolayer and actin cytoskeletal re-arrangement were reduced by CRX-526. Experiments were performed in triplicate.

B. \% area of gaps in the monolayer (quantified by Metamorph ${ }^{\circledR}$ software) was reduced by CRX526. 3 separate fields from each of 3 P30 dishes were analyzed ( $n=9$ photos/time point). $\mathrm{WI}=$ simulated warm ischemia; $r \mathrm{p}=$ simulated reperfusion. ${ }^{*} \mathrm{p}<0.05, \dagger \mathrm{p}<0.01, \neq \mathrm{p}<0.001$ unpaired t test.

C. Distributions of actin cytoskeletal re-arrangement at different time points in simulated warm IRI. Because of considerable variability in the actin cytoskeleton of HMVECs, cells were labeled as "normal" or "abnormal" actin distribution in images ( $\mathrm{n}=9$ photos/time point), without attempting to grade the severity of the abnormality. The assessment was made by a masked observer unaware of the group identity or the time of the sample, then ratios of populations were calculated. Approximately $40 \%$ of cells have some degree of peripheral orientation of the actin cytoskeleton in fresh control dishes. In cells subjected to simulated warm ischemia (WI), 
peripheral orientation of actin was significantly reduced in the presence of TLR4 inhibitor CRX526 following 60 minutes of WI and after 15 minutes simulated reperfusion (rep) compared to monolayers exposed to vehicle. $\ddagger \mathrm{p}<0.001$ unpaired $\mathrm{t}$ test.

Figure 7. TLR4-mediated alteration of HMVEC cytoskeleton due to IRI is ligand-independent. A. Quantification of gap area by Metamorph ${ }^{\circledR}$ software. WI-RL=media replaced by RL for 60 minutes. WI-RLM=RL from this ischemia experiment diluted with equal volume of fresh media; RLM=fresh RL mixed with equal volume of fresh media (glucose concentration is halved). HMVECs exposed for 60 minutes to WI-RLM or RLM do not develop significant gaps compared to HMVECs when media is replaced with RL (WI-RL). *p<0.01. B. RL removed from HMVECs following one hour of simulated ischemia (LR-WI) and placed on transfected AMs retrieved from HeJ and OuJ mice ( $\mathrm{n}=4$ each). There is no activation of NF$\kappa B$ by this RL-WI or fresh RL. 
Figure 1
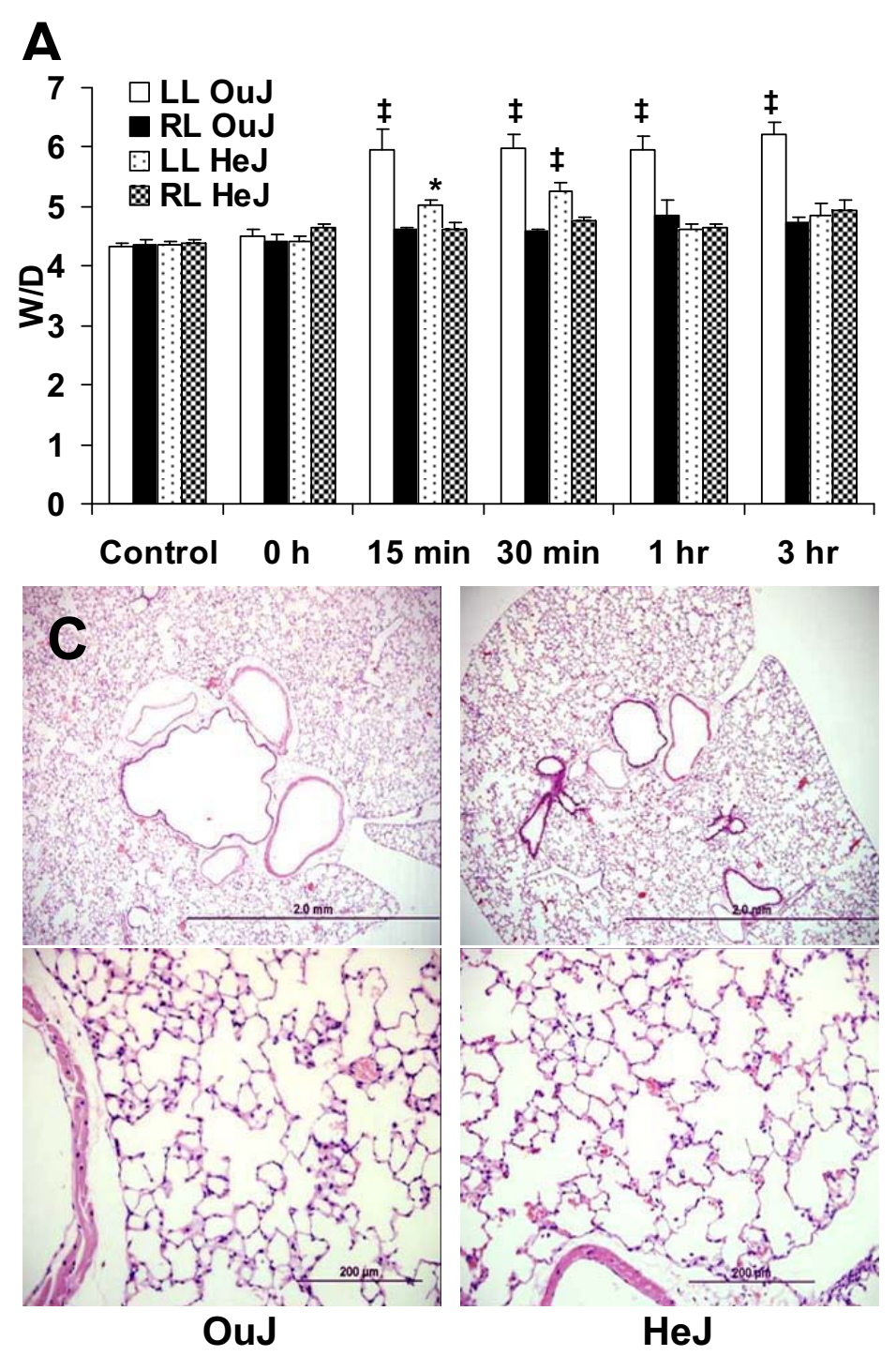

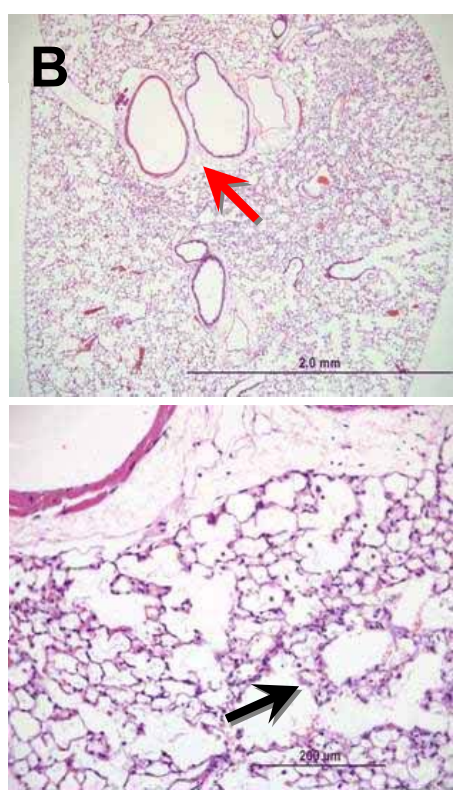

OuJ

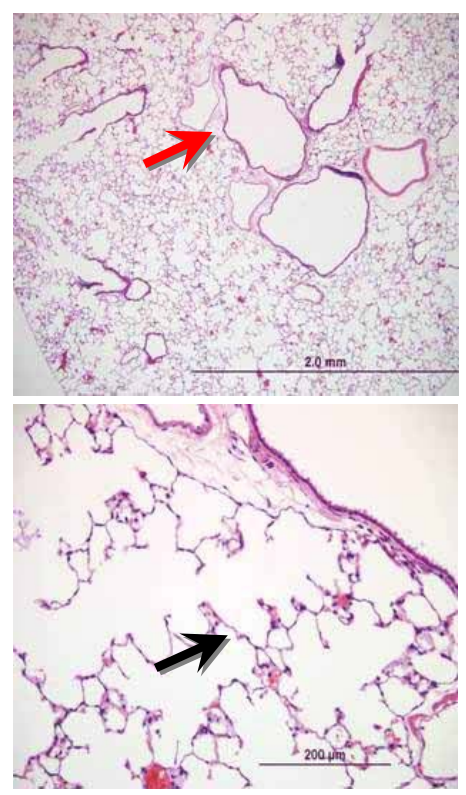

HeJ
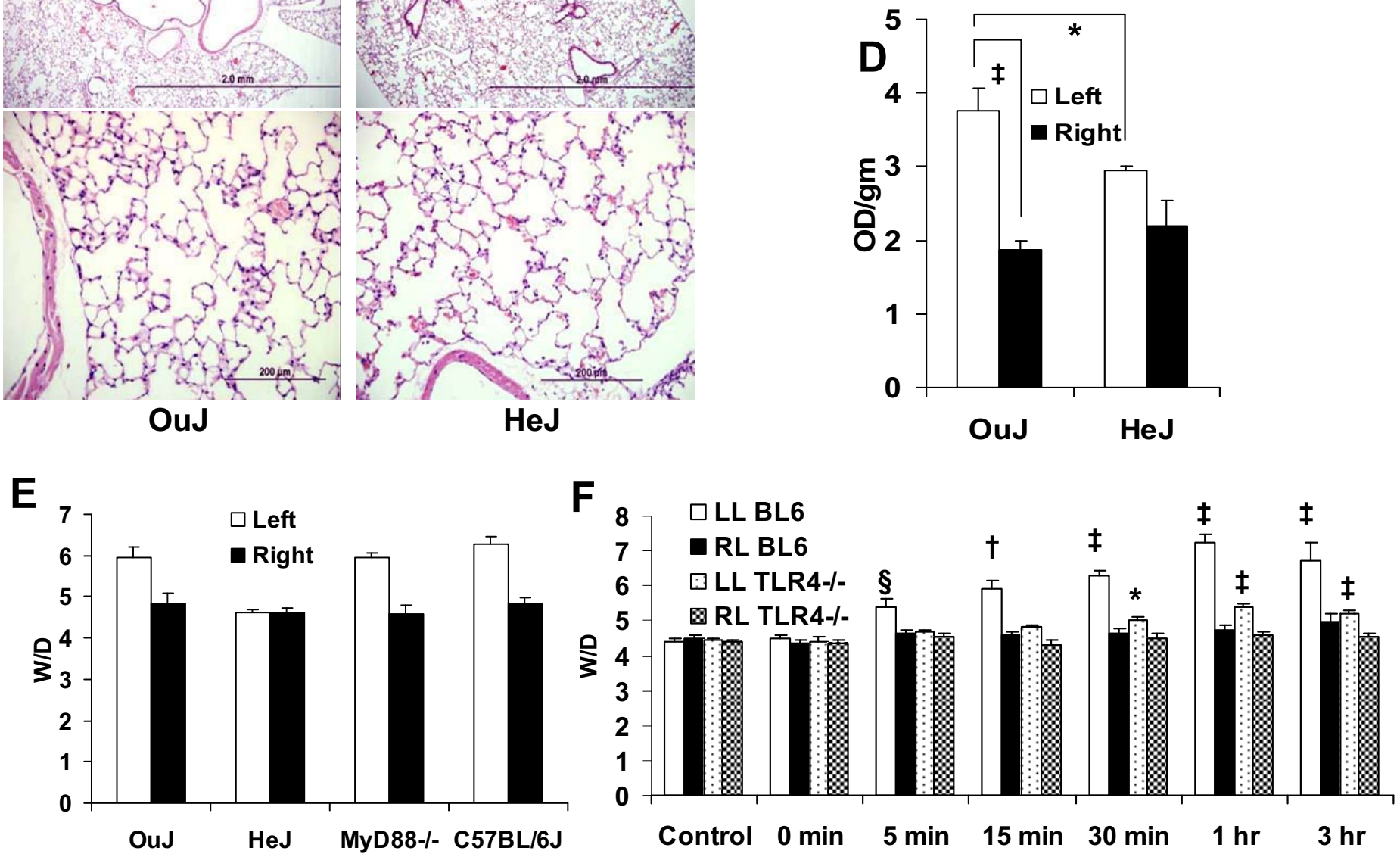


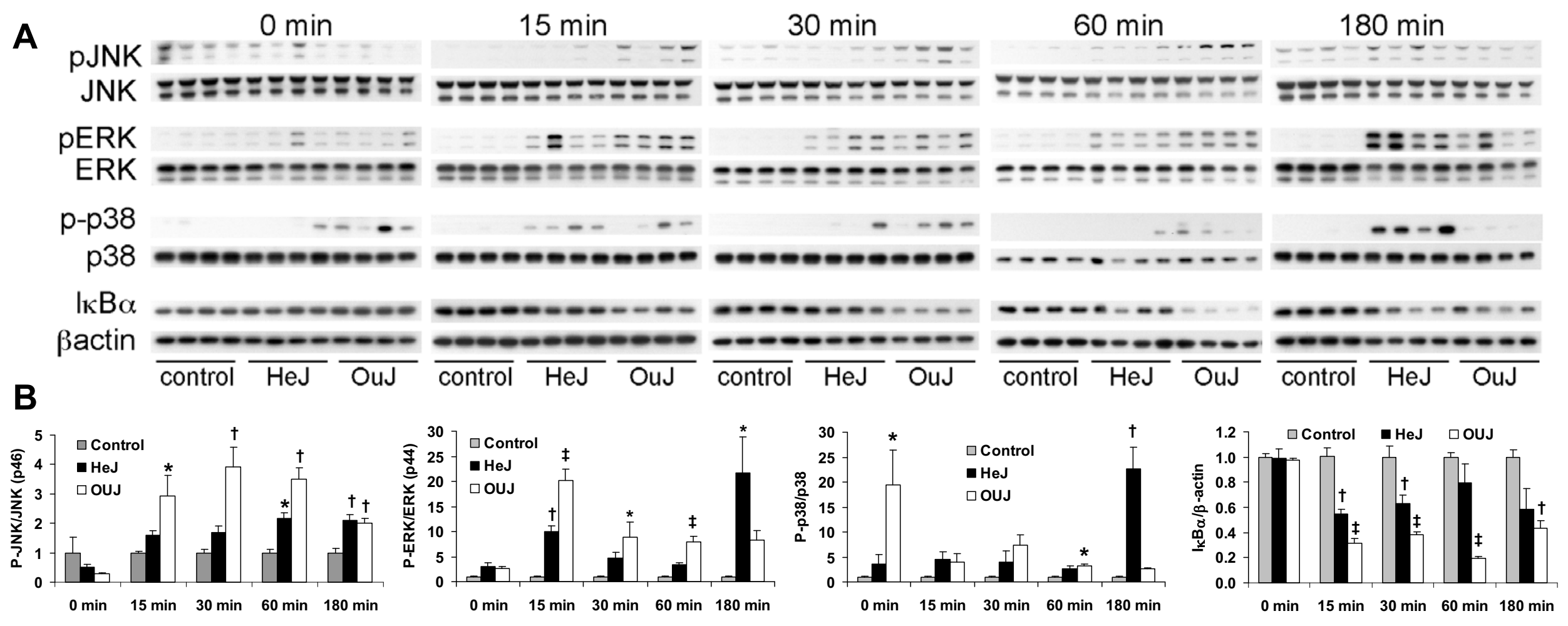

Figure 2 
Figure 3

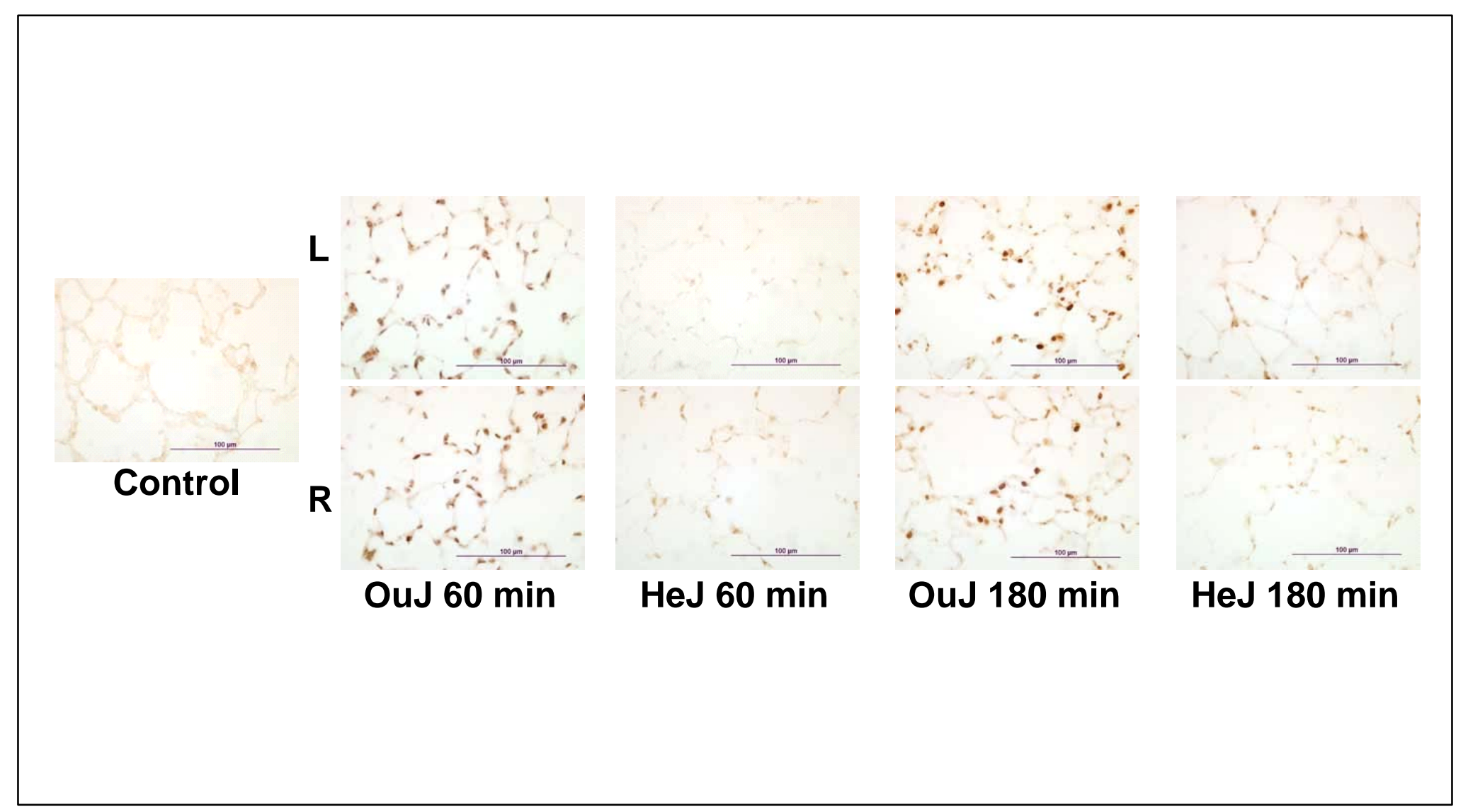


Figure 4

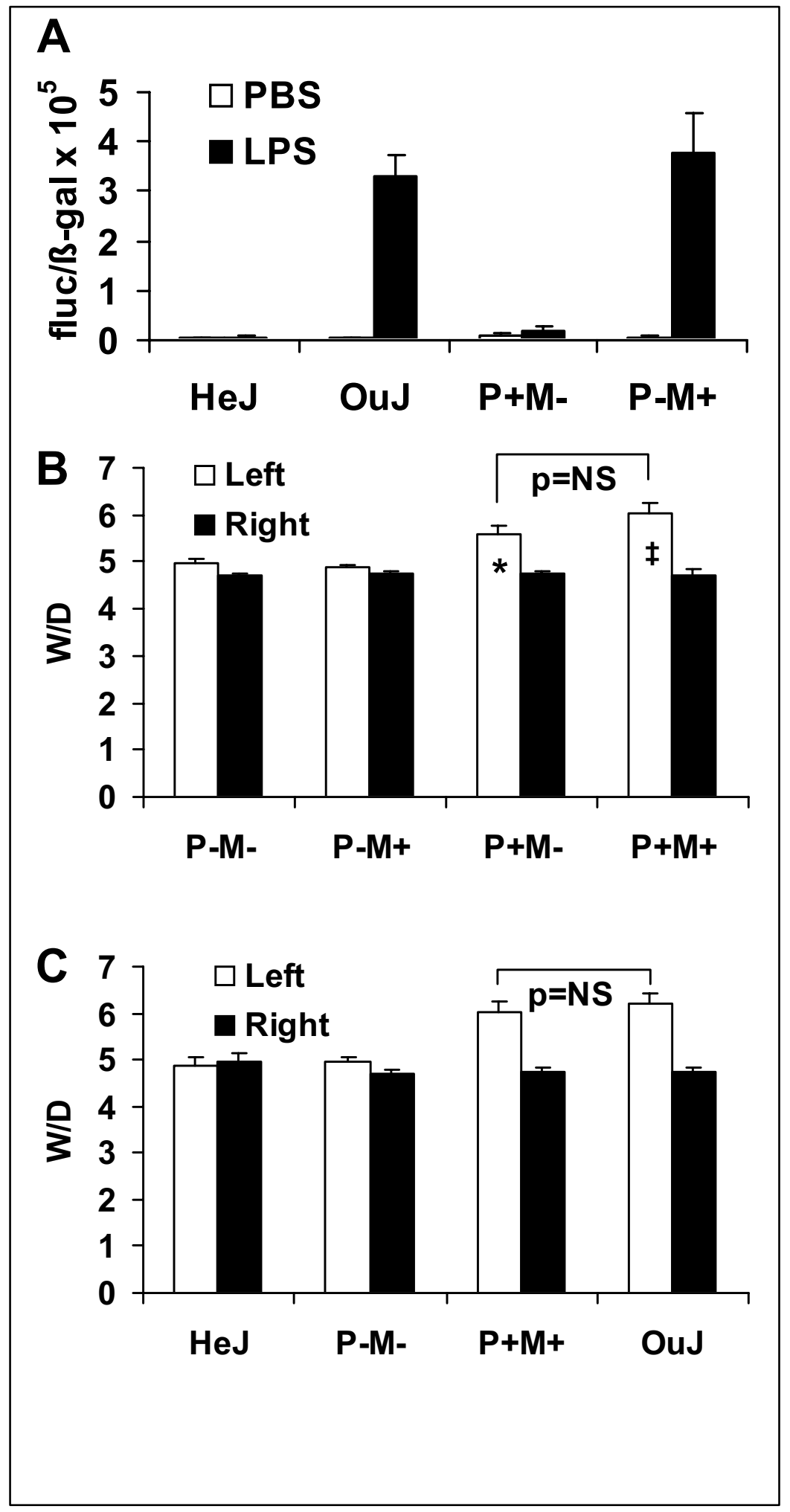


Figure 5

A

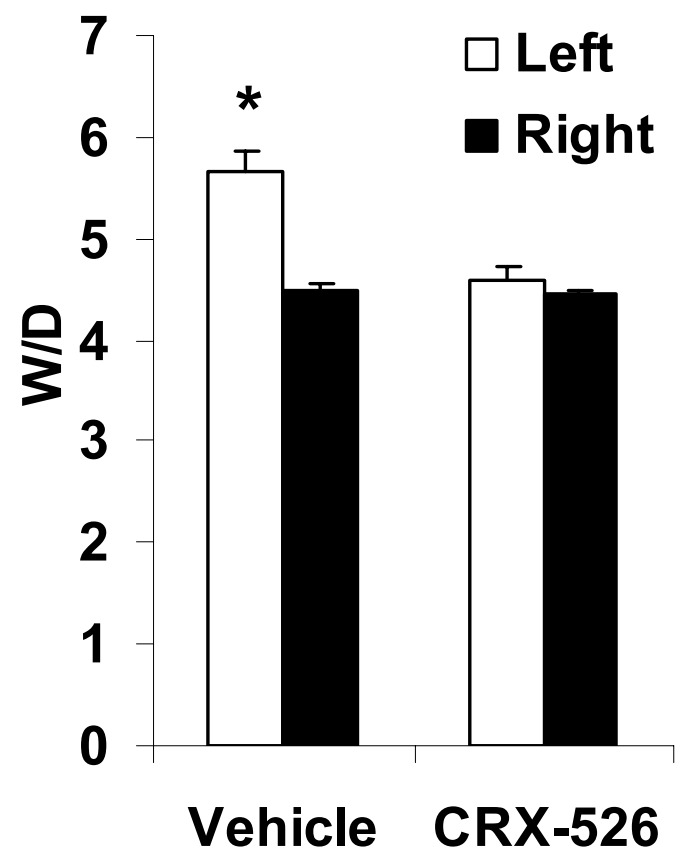

B

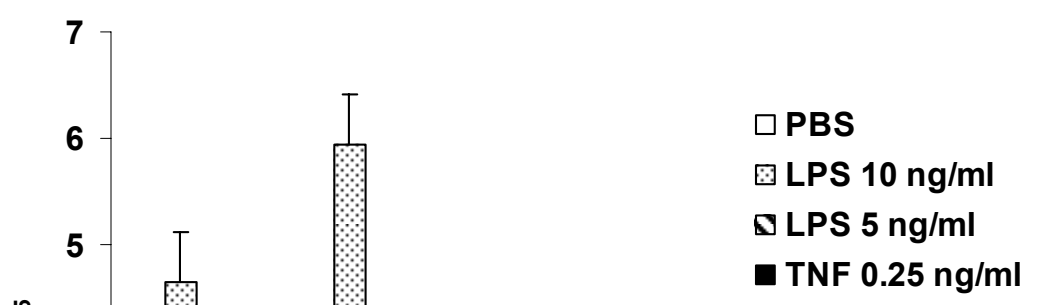

Control Vehicle Inhib 100 Inhib 10 Inhib 1 Inhib 0.1 
Figure 6

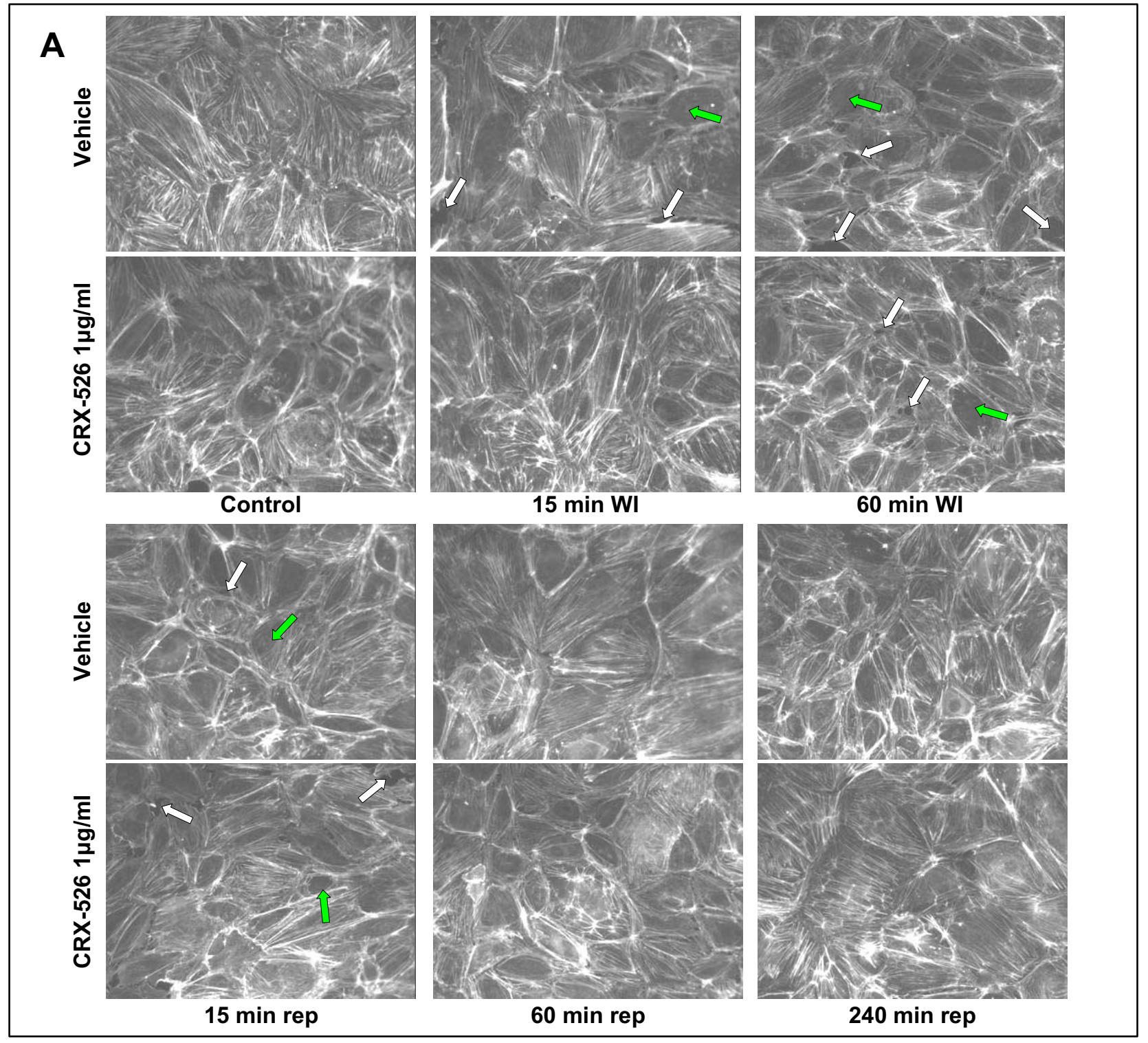




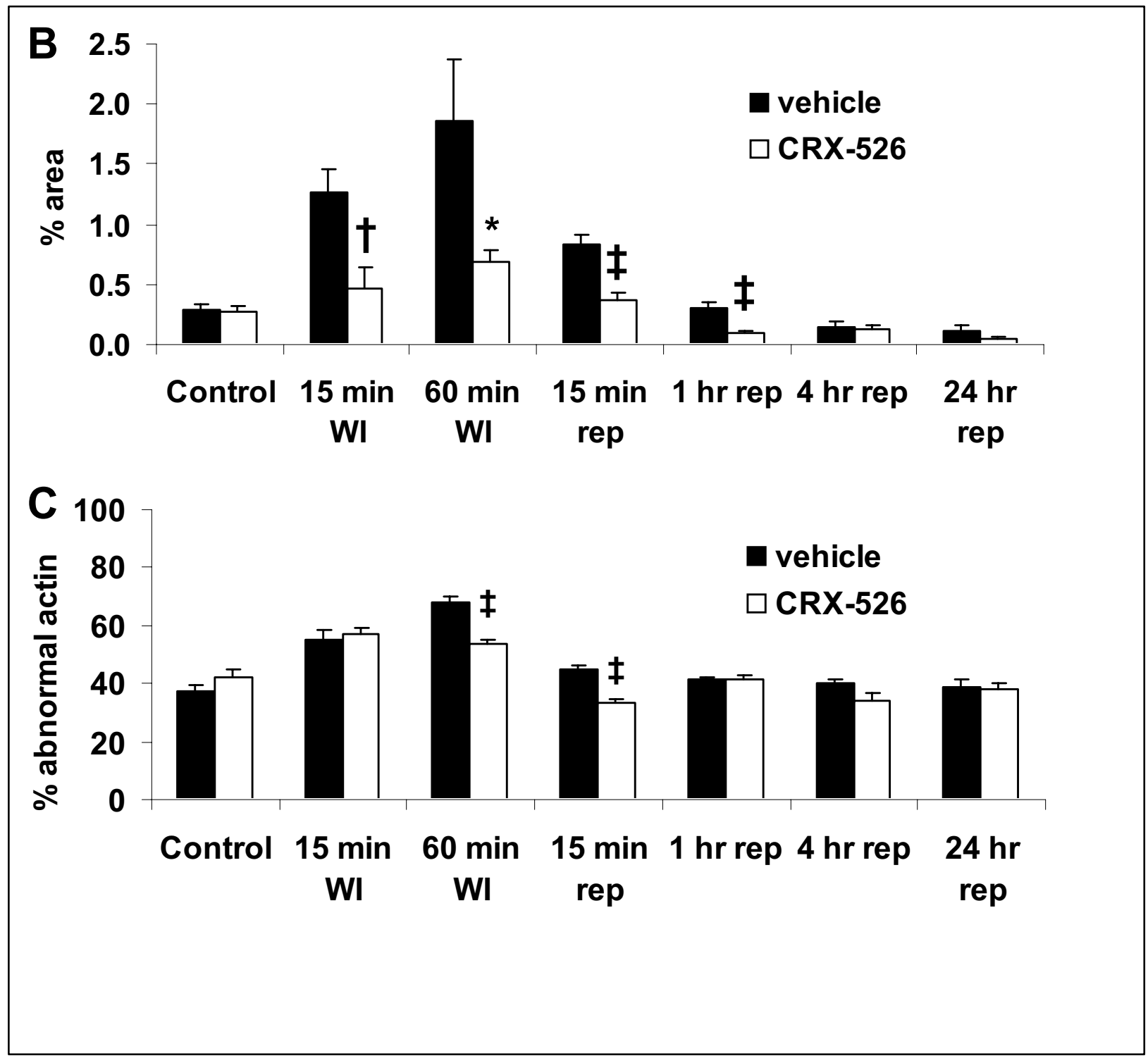


Figure 7

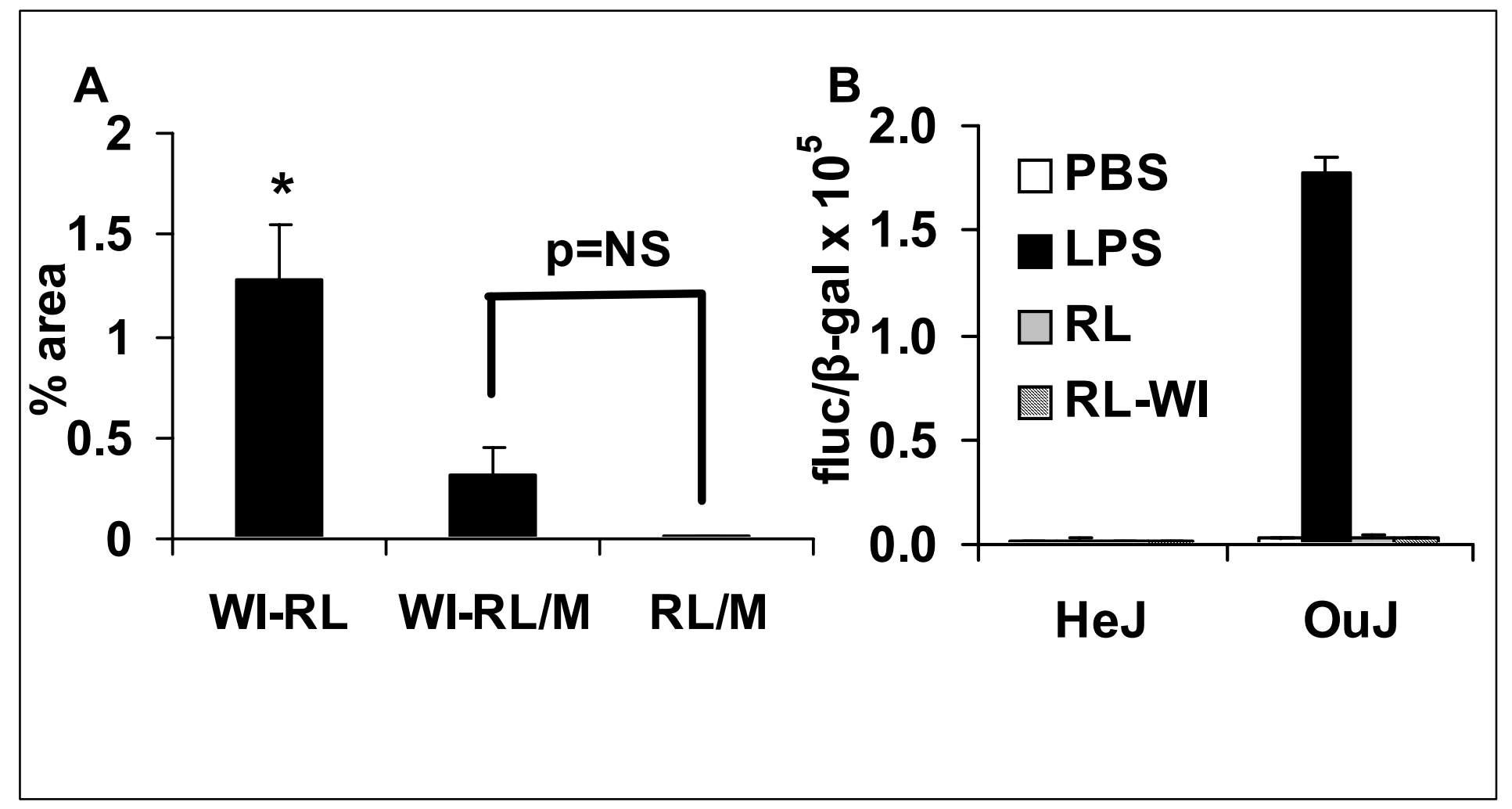

